Review

\title{
Surface Enhanced Raman Spectroscopy: Applications in Agriculture and Food Safety
}

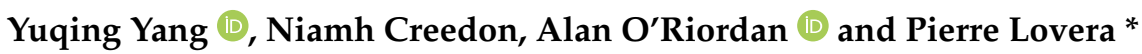 \\ Nanotechnology Group, Tyndall National Institute, T12 R5CP Cork, Ireland; yuqing.yang@tyndall.ie (Y.Y.); \\ niamh.creedon@umail.ucc.ie (N.C.); alan.oriordan@tyndall.ie (A.O.) \\ * Correspondence: pierre.lovera@tyndall.ie
}

\begin{abstract}
Recent global warming has resulted in shifting of weather patterns and led to intensification of natural disasters and upsurges in pests and diseases. As a result, global food systems are under pressure and need adjustments to meet the change- often by pesticides. Unfortunately, such agrochemicals are harmful for humans and the environment, and consequently need to be monitored. Traditional detection methods currently used are time consuming in terms of sample preparation, are high cost, and devices are typically not portable. Recently, Surface Enhanced Raman Scattering (SERS) has emerged as an attractive candidate for rapid, high sensitivity and high selectivity detection of contaminants relevant to the food industry and environmental monitoring. In this review, the principles of SERS as well as recent SERS substrate fabrication methods are first discussed. Following this, their development and applications for agrifood safety is reviewed, with focus on detection of dye molecules, melamine in food products, and the detection of different classes of pesticides such as organophosphate and neonicotinoids.
\end{abstract}

Keywords: Surface Enhanced Raman Scattering (SERS); fabrication; application; agriculture; food safety

check for updates

Citation: Yang, Y.; Creedon, N.; O'Riordan, A.; Lovera, P. Surface Enhanced Raman Spectroscopy: Applications in Agriculture and Food Safety. Photonics 2021, 8, 568. https:/ / doi.org/10.3390/photonics 8120568

Received: 27 October 2021

Accepted: 26 November 2021

Published: 10 December 2021

Publisher's Note: MDPI stays neutral with regard to jurisdictional claims in published maps and institutional affiliations.

Copyright: (c) 2021 by the authors. Licensee MDPI, Basel, Switzerland. This article is an open access article distributed under the terms and conditions of the Creative Commons Attribution (CC BY) license (https:// creativecommons.org/licenses/by/ $4.0 /)$.

\section{Introduction}

Climate change is manifesting itself with increased temperatures more favorable to spread of pests and diseases. This has resulted in more challenging food production as well as higher numbers of foodborne disease outbreaks. To try to protect yield and ensure food safety, farmers have little choice other than treating their crop with a range of pesticides [1] Unfortunately, there is more and more evidence showing that these phytosanitary products would do harm to humans, and also lead to the loss of biodiversity, leading to accumulation in soil and deleterious effects on indigenous microbiome [2]. As a result, it is necessary to monitor biological and chemical contamination in food systems throughout the whole food chain.

Traditional detection methods in food and agriculture systems are based on chromatography techniques coupled with mass spectrometry. These methods are time consuming, high cost, and laboratory based. Therefore, implementation of new portable technologies is needed to provide pesticide usage monitoring and regulation.

In this regard, Surface Enhanced Raman Spectroscopy (SERS) has recently attracted a lot of attention as it addresses these requirements. The advantages of SERS include ultrasensitive detection, fast turnover, in-situ sampling, on-site monitoring, low cost, portability of sensors, and the suitability for large-scale screening. Sensors based on SERS have been shown to provide real-time data on soil nutrients [3,4], monitor water run-off and contaminants in water supplies [5], and also detect pesticide residues in food [6,7]. The technique has also found applications in a wide range of sectors including the following: industrial, material, forensic, biological, food safety and electrochemical fields [8-18], with the most common chemical contaminants within environmental and food sectors being pesticides, adulterants, antibiotics and illegal drugs and illegal food dyes. 
In this paper, we review the main SERS substrate fabrication methods and bring a special focus on applications for the detection of hazardous chemicals in both food and agriculture.

\section{Raman Spectroscopy and Surface Enhanced Raman Scattering (SERS)}

Raman spectroscopy was first discovered in 1928 by Sir Chandrasekhara Venkata Raman. It was observed that when light excited a molecule, the majority of light was elastically scattered - this is Rayleigh scattering where $E_{\text {incident }}=E_{\text {scattered }}$, but also a small fraction of photons was inelastically scattered-this corresponds to Raman scattering where $\mathrm{E}_{\text {incident }} \neq \mathrm{E}_{\text {scattered }}$. When $\mathrm{E}_{\text {scattered }}<\mathrm{E}_{\text {incident, }}$ it is called a Stokes shift and when $E_{\text {scattered }}>E_{\text {incident, }}$ it is an anti-Stoke shift. Figure 1 shows an energy diagram for the two types of scattering $[19,20]$. Each peak on the Raman spectrum corresponds to a vibrational mode of the bonds of the molecule under Investigation. Raman scattering can occur in the near ultraviolet, visible, or near-infrared ranges [21,22]. However, Raman scattering efficiency is very low, with typically only 1 in $10^{8}$ incident photons being Raman scattered. This results in a low signal/noise ratio and can make it impractical and vulnerable to background interferences [23]. Fortunately, the efficiency of this scattering can be increased by using nanostructured plasmonic metals in a technique known as Surface Enhanced Raman Spectroscopy (SERS).

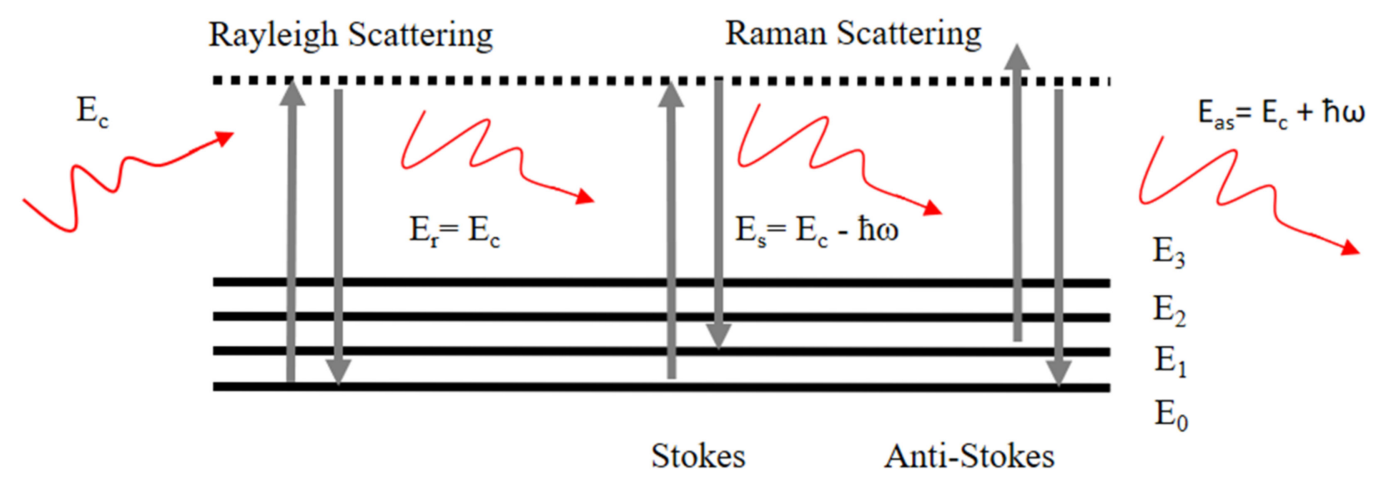

Figure 1. Schematics of energy levels of a molecule for Rayleigh and Raman Scattering [24].

SERS effects were first observed by Fleischman et al. in 1974, when acquiring Raman spectra of pyridine on electrochemically roughened silver [25]. In SERS, lasers are used to excite plasmons in nanostructured metallic surfaces ( $\mathrm{Au}, \mathrm{Ag}, \mathrm{Cu}$, etc.). The SERS enhancement is thought to be two-fold. The first enhancement is based on an electromagnetic enhancement $[26,27]$. due to localised surface plasmons, while the second originates from chemical resonant energy charge transfer $[25,28-30]$. The enhancement factor (EF) typically reaches $10^{6}$, which drastically improves the sensitivity of the plasmonic based device.

\subsection{Localized Surface Plasmon Resonance (LSPR)—Electromagnetic Enhancement}

When laser light excites a metallic nanostructure, the free electrons on its surface oscillate. This collective oscillation is known as Localised Surface Plasmon Resonance (LSPR) [31]. The excited LSPR makes a target molecule highly polarisable and forms a large electric field on the surface. This electric field induces dipole moments in a molecule on the surface of nanostructures, and sequentially produces Raman enhancement. These large, localised electromagnetic fields present around the nanostructures or in nano-gaps between closely-spaced nanostructures are known as "hot spots" [32], see Figure 2. The intensities of the Raman scattered photons are susceptible to enhancement, if their wavelengths are in resonance with the plasmon mode of the nanostructure. LSPR enhancement depends on the size, shape, composition, orientation and local dielectric of the nanostructure. This will be discussed in the next section. 


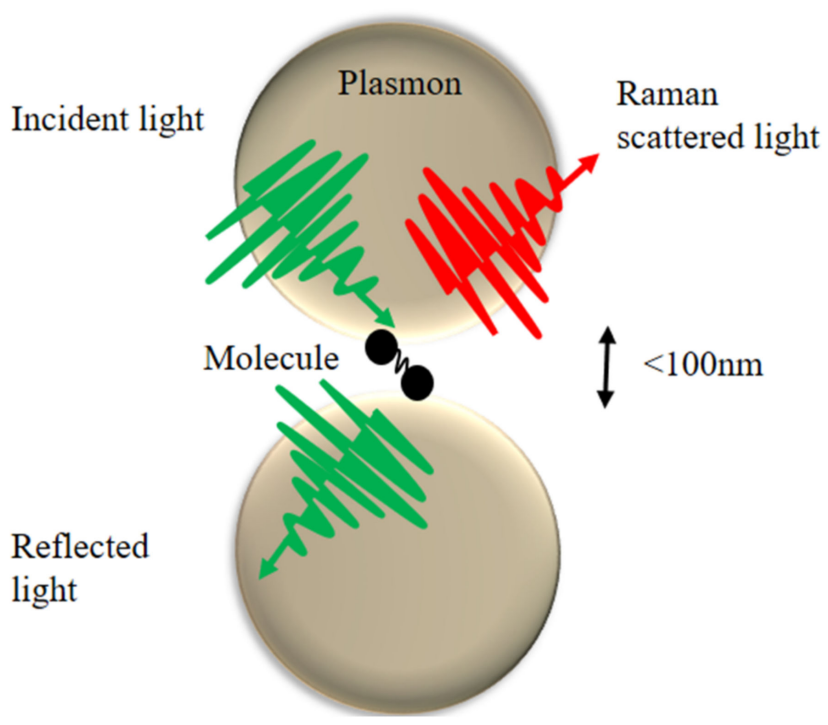

Figure 2. Plasmonic effects: Electric Field around two nanoparticles and the presence of a SERS "hotspot".

\subsection{Chemical Enhancement}

The origins of the chemical mechanism for SERS enhancement are still under discussion [33]. One hypothesis is that it is based on the change in polarisability of molecule adsorbed to a metal surface. Upon absorption of the incident laser light, charge transfer occurs between the molecule and the metal [34,35]. It is generally estimated that the chemical effect contributes to a factor of $10^{2}$ of the total SERS enhancement [36].

\subsection{Enhancement Factor (EF)}

The enhancement factor (EF) depends on molecular adsorption on plasmonic surface, as well as the morphology, roughness and homogeneity of this surface and the laser wavelength, etc. The calculation of the enhancement factor is $E F=\frac{I_{S E R S} /\left(\mu_{M} \mu_{S} A_{M}\right)}{I_{R S} /\left(C_{R S} H_{\text {eff }}\right)}$ [37], where ISERS is the intensity of Surface Enhanced Raman signal, $\mathrm{I}_{\mathrm{RS}}$ is the intensity of the normal Raman signal, $\mu_{M}\left(\mathrm{~m}^{-2}\right)$ is the surface density of NPs contributing to enhancement, $\mu_{\mathrm{S}}\left(\mathrm{m}^{-2}\right)$ is the surface density of molecules adsorbed to $\mathrm{NP}, \mathrm{A}_{\mathrm{M}}\left(\mathrm{m}^{2}\right)$ is the surface area of metallic NPs, $C_{R S}(M)$ is the concentration of the solution used for non-SERS measurements and $\mathrm{H}_{\text {eff }}(\mathrm{m})$ is the effective height of the scattering volume.

Experimental values of EFs are typically in the range of $10^{4}$ to $10^{6}$. However, electromagnetic "hotspots" are claimed to have provided massive enhancements of between $10^{11}$ to $10^{14}$ orders of magnitude of the SERS signal [38]. This theory is still being largely researched, as it is key to single molecule detection, which may be achieved from selective excitation of single molecules $[32,39,40]$.

\section{Fabrication of SERS-Active Substrates}

SERS substrates need nanostructured metallic surfaces with well-defined distances in the region of 10-100 $\mathrm{nm}$ between nano clusters [41]. By decreasing the distance between the nanostructures, the electric field becomes more localized and concentrated, and the corresponding SERS intensity signal increases accordingly. An example of this was discussed by Lee et al. where the distance between metallic clusters was decreased from $30 \mathrm{~nm}$ to $10 \mathrm{~nm}$, and an intensity increase of over 200-fold was observed [42]. There are two fundamentally different approaches to the development of SERS-active nanostructures with "hotspots": bottom-up assembly and top-down fabrication have been used [43]. 


\subsection{Bottom-Up Assembly}

Bottom-up approaches refer to the fabrication of nanostructures by chemical synthesis [44,45], colloid aggregation [41,46], electrochemical deposition [47-51], and selfassembly [52-54]. These methods have been used to fabricate a variety of nanostructures ranging from a few nanometers to a few hundred nanometers in size. Metal nanoparticles can be synthesised chemically at low cost with tailored geometries such as nanoparticles [55,56], nanowires [57,58], nanospheres [55,59,60], nanorods [61-64], nanotubes [65,66], nanotriangles [67], nano flower [68], nano-urchins [69], and nanoshells [70,71], see Figure 3. Besides pure metallic nanoparticles, composite materials such as bimetallic or hybrid nanostructures [72], Graphene Oxide/Au nanostars, [73], $\mathrm{SiO}_{2} @ \mathrm{TiO}_{2} @ \mathrm{Ag}$ [74] etc. and other composite material based on molecular imprint (MIP) have also attracted research attention [68,74-77] and have been reviewed recently [78].
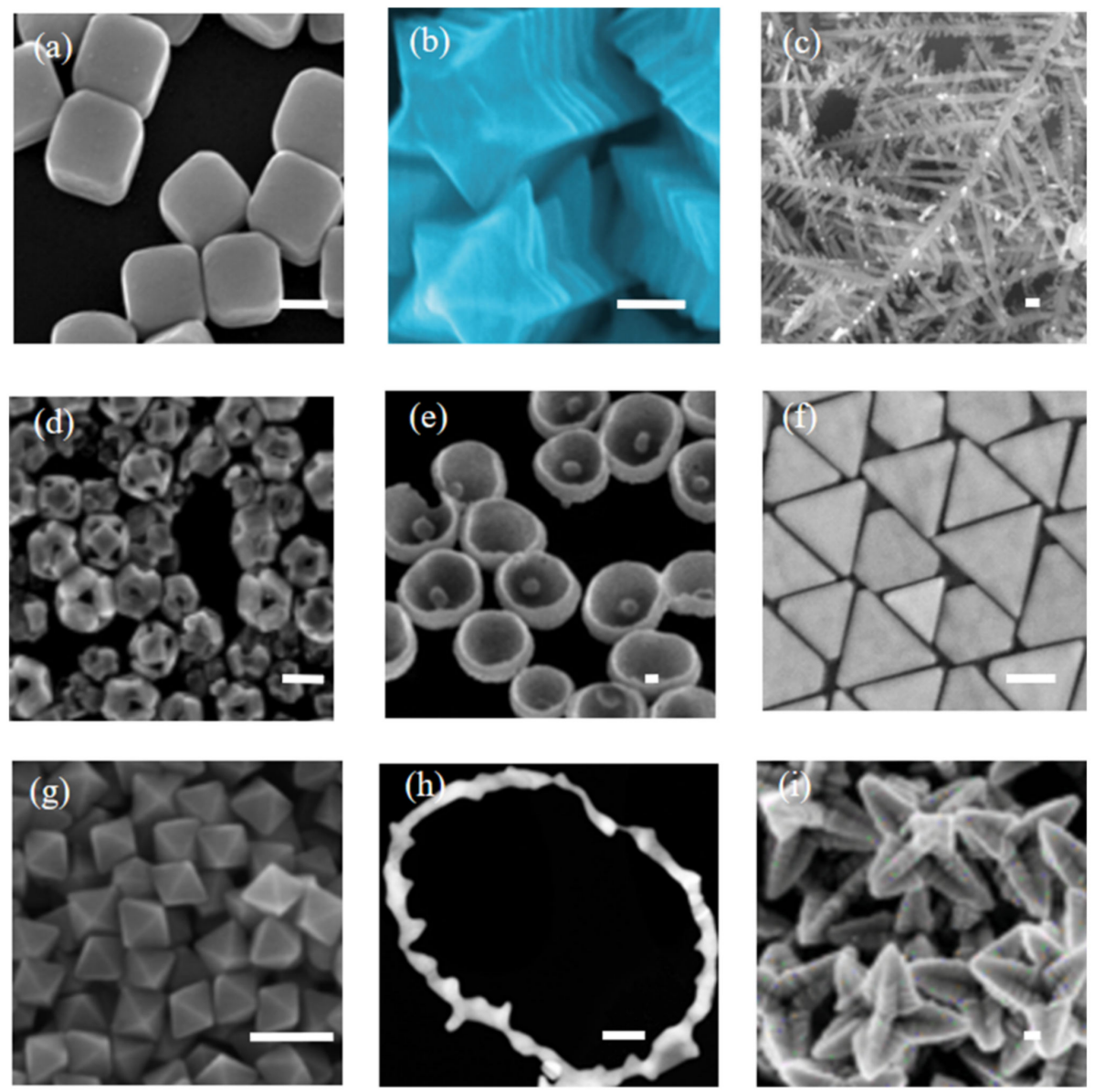

Figure 3. TEM/SEM images of (a) Ag/Au nanocubes [79], (b) GO/Au nanostars [73], (c) Ag nanodendrides [48], (d) Au nanocages [80], (e) Au nanobowls with Au seed inside [81], (f) gold nanotriangles [82], (g) Gold octahedrals [83], (h) Au nano ring [84], and (i) gold hollow stars [85]. Scale bar: $100 \mathrm{~nm}$.

Metal NPs such as gold or silver possess great potential for numerous applications in SERS $[86,87]$. The most common fabrication of SERS substrates are gold $(\mathrm{Au})$ and silver (Ag) colloids in diameters between 10 and $100 \mathrm{~nm}$, as they yield the greatest enhancements at their "hot spots". These nanoparticles constitute the fundamental SERS "building blocks" and can be assembled in different ways.

For example, they can be presented in a suspension or sol-gel in the presence of the analyte of interest [88-90]. The nanostructures, together with the analyte suspension, can then be drop-casted onto a substrate to create hot spots for Raman enhancement. The disad- 
vantage of this method is that the nanoparticle suspensions must be mixed with the analyte solution for SERS applications [91,92]. However, this drawback was addressed by Yang et al., who grew Ag nanoshells on thiol-modified silica NPs, and deposited them directly on apple skin for analysis [93]. Although there is a greater enhancement observed with these substrates, it is hard to obtain a homogeneous surface to get uniform enhancement. Additionally, they are not suitable for field analysis due to their complex sample preparation steps. In contrast, solid based devices may be more suited for portable and remote sensing, i.e., NPs that are immobilised on a solid substrate [94-97]. For example, Fan et al. fabricated self-assembled Ag NPs onto glass slides by using 3-mercaptopropyltrimethoxysilane (3-MPTMS) [97] This transformation stabilizes the Ag NPs, avoids the usual aggregation process and produces self-sustaining and portable SERS active substrates. Yu et al. fabricated silver colloidal nanoparticles for SERS analysis but alternatively injected them through a filter membrane, thus entrapping them in the filter. The filter therefore was used as the solid portable substrate. It demonstrated 1-2 orders of magnitude better SERS enhancement than the typical approach [98] In addition, Shiohara et al. fabricated gold nanostars and deposited them onto a polydimethylsiloxane (PDMS) platform for SERS evaluation. They used back side illumination for the detection of selected pesticide on fruit skin [99].

Other supports also add additional functionalities to SERS devices. Optical fiber-based SERS sensors have in this regard generated steady interest as a versatile means of extending SERS for portable field applications [63]. There is also a growing interest in the fabrication of flexible SERS substrates. These substrates are ultra-low cost, disposable, easy to use and highly suitable for on-site sensing applications. Polavarapu et al. fabricated SERS substrates by directly writing on paper using a pen filled with plasmonic nanoparticle inks to detect thiabendazole, which is a fungicide and parasiticide [100]. Lee et al. also fabricated SERS paper substrates impregnated with gold nanorods by dip coating [101] Chen et al. combined adhesive tape and SERS activity of Au nanoparticles to fabricate a "SERS tape" substrate. The Au particles were deposited onto the sticky side of the tape that was used to extract pesticides from different kinds of fruit and vegetable peels [102]. These flexible sensors fabricated by different methods dramatically improve the portability and feasibility of SERS detection for pollutants as a promising technique for both laboratory and field-based detection [102].

Overall, bottom up assemblies have shown very high enhancement but they often give inconsistent performance. This is mainly because of a lack of structural uniformity over the entire area of the substrate which could result in poor reproducibility and inhomogeneity, as different size, shape, composition, orientation and local dielectric of the plasmonic structure have different enhancement factors as mentioned before. The arrangements of the aggregates on the nanostructured surface are also hard to control.

\subsection{Top-Down Synthesis}

Top-down approaches for nanofabrication are scalable and highly reproducible. Topdown approaches include lithography techniques (electron-beam (E-beam) [103-105] and nanoimprint lithography $[106,107])$, laser etching together with film deposition (sputtering, metal evaporation, atomic layer deposition) $[108,109]$, templating (using anodic aluminium oxide [65], porous polymer (Polyester(PS) [110], masks or molds [57]), inkjet printing [111].

E-beam and nanoimprint lithography are fabrication methods used to create patterns with dimension down to $10 \mathrm{~nm}$. In E-beam lithography, the photon resist is crosslinked after being exposed to the electron beam. The exposed resist can then be washed away, leaving only the unexposed resist on the substrate. Metal layer is then evaporated onto the whole substrate and the unexposed polymer is then removed together with its metal over-layer, leaving only the metal pattern on the substrate. SERS substrates with various geometries such as nanoparticle dimers have been fabricated using E-beam lithography, see Figure $4 a-e$. 

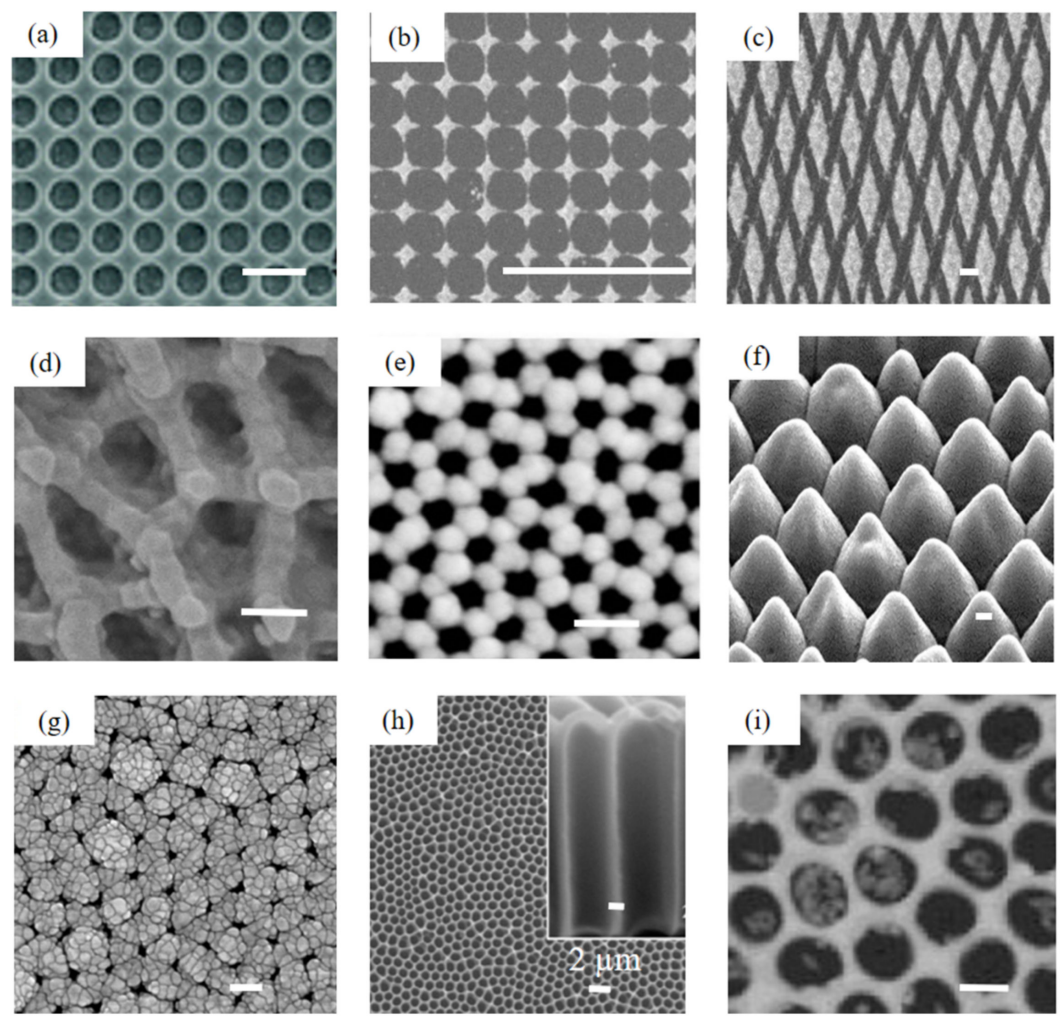

Figure 4. TEM and SEM images of top down approaches including E-beam fabricated (a) gold nanodisks [104], (b) Au star-like arrays [112], (c) Au diamond shaped structures [112], (d) Au dimple structures on PEN films treated by ion beam irradiation [113], (e) Au NPs distributed on the nanotips of canonical nanopores rims [114]; AAO templated structures: (f) Au nanostructure arrays [115], (g) Nano-flower like Ag/AAO [116], (h) Au nano-island @ Ag-frustum arrays [117], and (i) Au nanobipyramids self-assembled onto the AAO substrate [118]. Scale bars are all $100 \mathrm{~nm}$ without further indication in graphs.

Besides, Hu et al. fabricated polymer nanofinger structures on Si wafers using nanoimprint lithography, and coated the nanofingers with $70 \mathrm{~nm}$ of gold by e-beam evaporation, followed by exposure to solvent, inducing a leaning or self-closing of the nanowires, creating hot spots [119]. The fabricated arrays of electromagnetically coupled Ag nanoparticles on $\mathrm{Si}$, could increase Raman efficiency by controlling the interparticle separation between Ag nanoparticles. These substrates showed high SERS enhancement with good control and reproducibility. However, lithography based methods, although extremely tuneable and scalable, suffer from high cost, slow throughput and are time consuming.

Laser-induced fabrication of SERS substrates has attracted research attention as it is scalabe and cost-effective. The fabrication of laser-induced SERS substrates always involves two steps. Firstly, fabrication of a nano/micro patterned substrate using ultra-fast laser pulses followed by physical vapor deposition to deposite the metal layer on the nano/micro patterned substrates in order to get plasmonic structures. Yang et al. used a nanosecond pulsed laser $(1064 \mathrm{~nm}$, pulse duration $(\tau)$ (full width at half maximum, FWHM) $5 \mathrm{~ns}$, pulse repetition rate (PRR) $100 \mathrm{kHz}$, spot size $20 \mu \mathrm{m}$ and laser ablation speed $(v) 100 \mathrm{~mm} / \mathrm{s}$ ) ablation system to create micropatterns and generate different size nanoparticles [108]. The ablated Si surfaces were then deposited with Ag by electron beam evaporation. The enhancement factor of the fabricated substrates was estimated to be $\sim 5.5 \times 10^{6}$. Diebold et al. fabricated Ag SERS substrate using a femtosecond laser (100-fs pulses at a repetition rate of $1 \mathrm{kHz}, 800-\mathrm{nm}$ center wavelength) structuring process [120]. This pulse train was frequency-doubled to a center wavelength of $400 \mathrm{~nm}$ through a thin $\mathrm{BiBO}_{3}$ crystal. They used an n-type silicon wafer as the substrate. These laser pulses had an average fluence 
of $10 \mathrm{~kJ} / \mathrm{m}^{2}$ at the surface of a silicon wafer. A thermal deposition at a rate of $0.15 \mathrm{~nm} / \mathrm{s}$ onto the structured silicon with different thicknesses of 10, 30, 60, 80, 100, and $200 \mathrm{~nm}$ was undertaken to get the optimized Ag nanostructure sizes for enhanced SERS performance. Similarly, Indrè Aleknavičienè et al. fabricated fast and scalable SERS substrates at low cost using ultrashort-pulse laser-induced ( $280 \mathrm{fs}, 100 \mathrm{kHz}, 350-380 \mathrm{~nJ}$ ) plasma-assisted ablation (LIPAA) of soda-lime glass. The fabrication speed was as fast as $150 \mathrm{~mm} / \mathrm{s}$ [121]. After the amorphous nanostructure formation on the glass surface, deposition of a $170 \mathrm{~nm}$ silver layer by vacuum deposition (around $100 \mathrm{~nm}$ in diameter, forming 1-3 $\mu \mathrm{m}$ size dendrimers) was applied to the glass substrate. This SERS substrate achieved an average enhancement factor (EF) of $3.0 \times 10^{5}$ evaluated using thiophenol.

Inkjet printing combined with electrochemical deposition is more convenient than e-beam lithography in terms of time and cost, and allows larger area fabrication at the same time. Inkjet printing method can be used both on solid substrate or on flexible substrate [122-134]. However, the choices of ink for inkjet printing are currently limited.

SERS substrates fabricated by templating methods is another widely used approach and has been demonstrated by a number of groups, see Figure $4 \mathrm{f}-\mathrm{i}$. Shanshan Shen et al. have studied substrates based on CdTe quantum dots modified polystyrene (PS) spheres with Ag nanoparticle caps. These substrates showed high enhancement factor $\left(0.71 \times 10^{6}\right)$ by using 4-ATP as the model molecule. [135]. Another very popular method is to use Anodised Aluminium Oxide (AAO) as a template to produce nanotubes [136]. Aluminium foil is anodised in acid to create nanopores, which are then used as a template to fabricate SERS substrates. Metals can be pulsed electrodeposited inside the template channels [137], or deposited via electron beam evaporation [138]. Alternatively, polymers can be employed to template the AAO. Lovera et al. fabricated super hydrophobic PS nanotubes by wetting commercial AAO filters and depositing silver onto the resulting PS nanotube structures [65]. Similarly, Zhang et al. patterned Polyethylene terephthalate (PET) on a nanostructured AAO template and deposited $\mathrm{Au}$ onto the polymer to create $\mathrm{Au}$ ananosturcture arrays. [115]. Other templates used for the fabrication of nanowires and nanotubes for SERS substrates include Polycarbonate membranes (PCM) [139-141], Polystyrene microspheres (PSM) [142-144] and nanochannel glasses. Charconnet et al. fabricated superlattices by templated self-assembly of gold nanoparticles on a flexible support, with tunable lattice-plasmon resonances through macroscopic strain. They found that the highest SERS performance was achieved by matching the lattice plasmon mode to the excitation wavelength, by post-assembly fine-tuning of long-range structural parameters [145]. The above substrates fabricated with "top-down" methods are manufactured reproducibly with high throughput, but often produced weaker signals than 'bottom-up' method due to larger distance between the nano structures and smaller surface density for nano particles that contribute to SERS signal. It involves also the use of expensive equipment and/or complex procedures. Combination of bottom-up and top-down fabricate method could increase the Raman intensity by creating a rougher and more homogeneous plasmonic surface [146].

\section{Chemical Functionalization of SERS Substrates}

SERS substrates without functionalization have limitations when dealing with real samples, e.g., strong background noise from the environment, or dealing with macro molecular such as DNA/proteins, which would block the SERS signal. For this reason, functionalization of SERS substrates is often undertaken to improve the selectivity or sensitivity in identifying the specific target analyte, which could lower detection time and limit of detection (LOD) [147]. The most widely used functionalization method is the attachment of self-assembled monolayer (SAM) of thiols to the silver or gold metallic nano structures. Functional groups along the thiol are used to phyisorb or chemically bind the analyte of interest to the substrate, thereby pre-concentrating the analyte at the surface leading to a subsequent increased in sensitivity. The thiol attaches to the metal nano structure surface owing to the strong affinity of sulphur with metals. However, the mechanism for the thiol group binding to the metal surface is not totally understood yet. One theory is that the 
thiol moieties chemisorb to planar gold surfaces, with the loss of hydrogen during the formation of the bond [148]. In 2003, Meirav Cohen-Atiya et al. studied adsorption of thiols on different metal surfaces by potentiometric measurements [149]. This adsorption process involves several complex steps including negative charge transfer and discharge through a reduction process. These steps related to the metal, the surface state of the metal, and the end functional groups in thiols. In 2014, Xue et al. used AFM to study the force between $\mathrm{Au}$ NPs and thiols under different experimental condition including oxidized $\mathrm{Au}$ surface and reduced Au surface with different $\mathrm{pH}$ effects; they stated that the bond between $\mathrm{Au}$ and thiol is a covalent bond [150]. In 2019, Inkpen and colleagues suggested that in gold-thiol SAMs prepared from solution deposition of dithiols, the gold-sulfur coupling had a physisorbed character, by both experiment and density functional theory (DFT) caculation [151]. Henrik Grönbeck et al. suggested the role of the thiol chain length must be considered when accessing the stability of monolayer systems on surfaces and clusters [152]. The formation of the Metal-S bond was not always very strong and the attachment of the thiol to the metal surface often happens in a few seconds. In order to gain homogeneous thiol self-assembly layer, longer incubation times, typically $24 \mathrm{~h}$, are required. Thiol concentration affects binding result [153], and spacing between thiols can be adjusted by adding different thiols. Some bio-sensors based on thiolated single stand-DNA [154] or thiolated anti-body [155] have been used to detect DNA/RNA/antigen in environment, while thiol-aptamers are also used for DNA detection, see Figure 5.

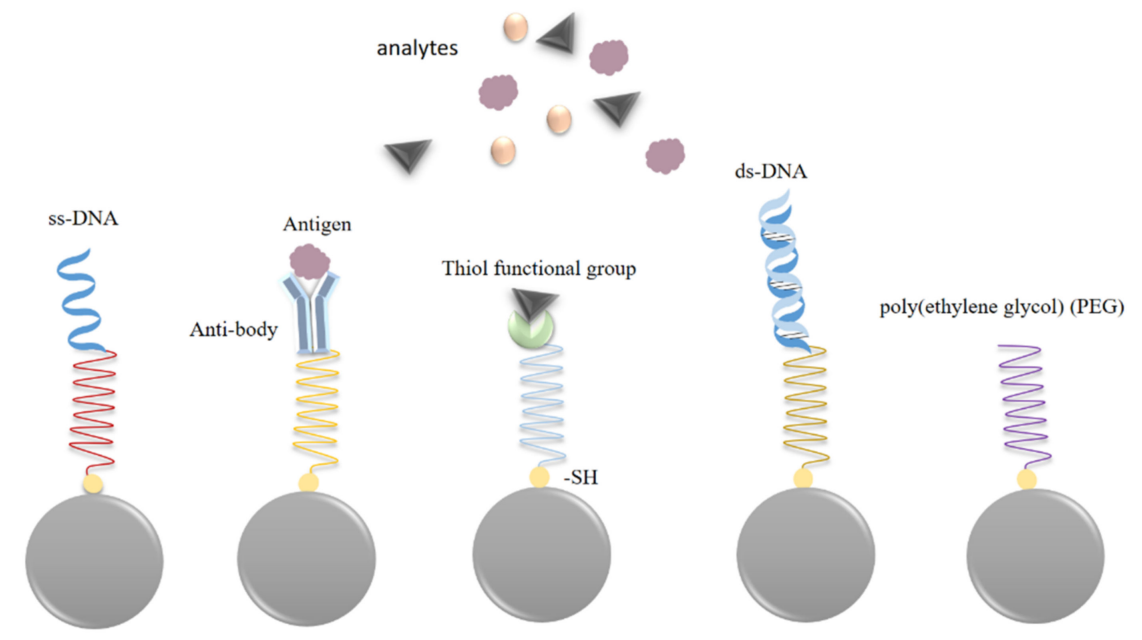

Figure 5. Different functionalisation thiols applied to metal nanoparticles: thiol-ss-DNA, thiolanti-body, thiol-ds-DNA, thiol-PEG.

The interaction between antibody-antigen is considered strong due to the presence of electrostatic forces such as hydrophobic interactions, hydrogen bonds, van der Waals forces or ionic bonds [156]. Functionalization of SERS substrates with antibodies has gained much interest in recent years because of the significant level of sensitivity and selectivity that can be achieved with them [157]. Aptamers are single-stranded DNA sequences that can be designed to capture specific chemicals. Thiolated aptamers conjugated onto metal nano structures can capture and combine with the targeted chemicals to get surface enhanced Raman spectra. Sensors based on aptamers and SERS have been used for detecting pesticides, DNAs, RNAs, uranyl, biotoxin, pathogen, hazard foodborne etc. [158-163]. Gold/silver nanoparticles modified with polyethylene glycol (thiol-PEG) provide a capping system that stabilizes the antibody and avoid the reticular endothelial system $[129,164,165]$.

\section{Application of SERS in Agri-Food}

\subsection{Detection of Pesticide Residues}

According to The United Nations Population Division, it is estimated that in 2050, the global population will reach $\sim 9.7$ billion, $30 \%$ more people than in 2017. A key challenge 
therefore, is that food production must keep pace with population growth. To this end, a variety of interventions have been put in place over the years to reduce losses due to disease and pests. Pesticide usage is essential in modern agricultural practices to protect crops and increase yield. There are currently more than 1000 pesticides used commercially around the world to ensure food is not damaged or destroyed by pests. Each pesticide has different properties and toxicological effects. The main drawbacks of pesticides is their potential toxicity to humans and other non-targeted organisms, which can result in significantly reduced biodiversity, through environmental contaminations in soil, water, and other vegetation $[166,167]$. The widespread use of pesticides therefore needs to be monitored and controlled [168].

Pesticides are classified by (i) the mode of entry, (ii) their function and the pest organism they kill, and (iii) their chemical composition. Based on chemical composition, pesticides are classified into four main groups, namely, organochlorines, organophosphorus, carbamates and pyrethrin/pyrethroids; see Table 1. Organochlorines pesticides (also known as chlorinated hydrocarbons) are organic compounds attached with five or more chlorine atoms. Organophosphates are derivatives of phosphoric acid, while carbamates derived from carbamic acid. Synthetic pyrethroid pesticides are group of organic pesticide that can be synthesized by duplicating the structure of natural pyrethrins.

Table 1. Four categories of pesticides classified by chemical composition.

\begin{tabular}{ccc}
\hline Pesticides Category & Examples & Degradation in the Environment \\
\hline Organo-chlorines & $\begin{array}{c}\text { DDT, Chlorinated cyclodienes (aldrin, dieldrin, endrin, } \\
\text { heptachlor, chlordane and endosulfan), dicofol, mirex, } \\
\text { kepone, and pentachlorophenol }\end{array}$ & $\begin{array}{c}\text { Long term residual effect in the } \\
\text { environment }\end{array}$ \\
Organo-phosphates & $\begin{array}{c}\text { Parathion, malathion, methyl parathion } \\
\text { chlorpyrifos, diazinon, dichlorvos, phosmet, } \\
\text { fenitrothion, tetrachlorvinphos, azamethiphos, } \\
\text { azinphos-methyl, terbufos }\end{array}$ & Biodegradable \\
Carbamates & $\begin{array}{c}\text { Aldicarb, carbofuran, carbaryl, ethienocarb, } \\
\text { fenobucarb, oxamyl, and methomyl. }\end{array}$ & $\begin{array}{c}\text { Easily degraded under natural } \\
\text { environment with minimum } \\
\text { environmental pollution }\end{array}$ \\
\hline Pyrethroids & delatmethrin, cyfluthrin, befenthrin, \\
lambda-cyhalothrin, permethrin. & $\begin{array}{c}\text { Non-persistent, and break down easily on } \\
\text { exposure to light. }\end{array}$ \\
\hline
\end{tabular}

Current detection methods of pesticides include high pressure liquid chromatography (HPLC), gas chromatography (GC), liquid chromatography (LG), mass chromatography (MC), spectrofluorimetric techniques as well as electrochemical methods. Han et al., for example, reported 302 targeted contaminants in catfish muscle by fast low-pressure GCMS/MS and UHPLC-MS/MS methods [169]; Velkoska-Markovska, L. et al. detected malathion using liquid chromatography [170]; Wang et al. detected organic phosphates (OPs) using fluorescent probe [118]. Geto et al. used screen-printed carbon electrodes electrochemical sensors to detect bentazone in water source [171]. Santana et al. detected Carbendazim using electrochemical detection [172].

There are growing demands for the development of novel analytical techniques for a variety of pollutants affecting crops, for example, pesticides. In this respect, methods based on SERS have attracted attention. The first SERS study of pesticides was the detection of organophosphorus pesticides in 1987 by Alak et al. [173]. Since then, the potential toxicity to humans, animals, and the environment has been reported, and tolerance levels were introduced for a large number of harmful pesticides $[174,175]$. SERS detection methods have developed considerably, resulting in a large number of the more recent reports employing in-situ SERS detection methods on the surface of different foods [93,176]. A search on Web of Science with key words combining the topics of "surface enhanced Raman" and "pesticides" revealed 432 publication results up to 12 November 2021. The majority of SERS 
and pesticide-related researches demonstrated detection of organophosphate (OP) insecticides, for example, phosmet [176,177], parathion-methyl [178], malathion [170,179,180], chlorpyrifos [181-183]; see Table 2. Other SERS pesticide studies included fungicides (thiram [184], thiabendazol $[185,186])$, herbicides [179,180,187,188], and neonicotinoids insecticides (imidacloprid [189], thiacloprid [190], acetamiprid [191,192]).

Amongst the pesticides, organophosphates (OP) represent the largest class, making up to $50 \%$ of the neurotoxic agents in chemical pesticides [193]. Most OP usage is agricultural, since the Environmental Protection Agency banned their residential use in 2001 [194]. However, their human and animal toxicity still make them a societal health and environmental concern [195-197]. Moreover, pesticides at low concentration have been detected in food and drinking water [182,198-201]. Liu et al. reported on the use of silvercoated gold bimetallic nanoparticles; their Raman Enhancement depends on the silver shell thickness, for in situ detection of a range of pesticides on fruit peels without further sample preparation, with a limit of detection (LOD) below the required maximum residue levels (MRL) [202]. However, as described above, colloidal based solutions are not ideal for portable applications while solid SERS substrates that can be prepared in advance are more suitable. For example, Chen et al. used "SERS tape" to extract OP pesticides (thiram, chlorpyrifos, methyl parathion) from different kinds of fruit and vegetable peels [102]. The tape is placed on to the surface of the produce and peeled off for SERS analysis. This is non-invasive and requires no sample or substrate preparation. Additionally, Li et al. have created a 'smart dust' that easily spreads over a probed surface for in-situ SERS measurements [203]. This method requires no preparation or particle aggregation/concentration on the substrate. Their shell-isolated nanoparticles are used to analyse residues of OP pesticide parathion, on a fresh orange. They present comparable results between a normal Raman and a portable Raman, demonstrating the substrates potential use in-field.

Table 2. Organophosphates (OP) detection by SERS in food industry and environment monitoring.

\begin{tabular}{|c|c|c|c|c|c|}
\hline Organophos & hates (Matrix) & SERS Substrate & LOD (Reported) & $\begin{array}{c}\text { LOD } \\
\text { (Normalised) }\end{array}$ & $\begin{array}{c}\text { Excitation } \\
\text { Wavelength }\end{array}$ \\
\hline \multirow{5}{*}{ Phosmet } & Ooling tea [204] & Ag NPs & $0.1 \mathrm{mg} / \mathrm{kg}$ & $0.1 \mathrm{ppm}$ & $633 \mathrm{~nm}$ \\
\hline & fruit [205] & $\begin{array}{l}\text { multi-walled carbon } \\
\text { nanotubes }\end{array}$ & $0.5 \mathrm{mg} / \mathrm{kg}$ & $0.5 \mathrm{ppm}$ & $785 \mathrm{~nm}$ \\
\hline & paddy water [206] & Au nanorods & $0.25 \mathrm{mg} / \mathrm{L}$ & $0.25 \mathrm{ppm}$ & $\begin{array}{c}\text { Portable Raman } \\
\text { spectrometer, } \\
785 \mathrm{~nm}\end{array}$ \\
\hline & fruit skin [207] & polyurethane-Ag NPs & $0.6 \mu \mathrm{g} / \mathrm{mL}$ & $0.6 \mathrm{ppb}$ & $785 \mathrm{~nm}$ \\
\hline & Plant Surfaces [208] & $\begin{array}{l}\text { polyurethane } \\
\text { micelle/Ag NP }\end{array}$ & $0.08 \mathrm{~g} / \mathrm{mL}$ & 80 ppm & / \\
\hline \multirow{3}{*}{ Parathion-methyl } & $\begin{array}{l}\text { fruit or vegetable } \\
\text { peels [209] }\end{array}$ & $\begin{array}{c}\text { Snowflake-like Au } \\
\text { NPs }\end{array}$ & $0.026 \mathrm{ng} / \mathrm{cm}$ & / & $638 \mathrm{~nm}$ \\
\hline & solvent [210] & $\begin{array}{l}\text { Ag NP decorated } \\
\text { ZnO-nanorods }\end{array}$ & $10^{-8} \mathrm{M}$ & $2.63 \mathrm{ppb}$ & $532 \mathrm{~nm}$ \\
\hline & solvent [211] & nanoporous structure & $12 \mathrm{ppb}$ & $12 \mathrm{ppb}$ & $785 \mathrm{~nm}$ \\
\hline Malathion & solvent [212] & nanostructured $\mathrm{Ag}$ & $10 \mathrm{nM}$ & $3.30 \mathrm{ppb}$ & $632.8 \mathrm{~nm}$ \\
\hline \multirow{3}{*}{ Chlorpyrifos } & tomato surface [183] & Ag colloid & $10^{-9} \mathrm{~mol} / \mathrm{L}$ & $0.35 \mathrm{ppb}$ & $638 \mathrm{~nm}$ \\
\hline & soil [213] & $\mathrm{Au} \mathrm{NP}$ & 10 ppm & 10 ppm & $785 \mathrm{~nm}$ \\
\hline & fruits [214] & Ag NP & $10 \mathrm{ng} / \mathrm{mL}$ & $10 \mathrm{ppb}$ & $633 \mathrm{~nm}$ \\
\hline
\end{tabular}

Neonicotinoids are a more recent and relatively powerful class of insecticide, and since the introduction of imidacloprid in 1991, they have been the fastest-growing class of insecticides in modern crop protection [215], representing almost $17 \%$ of the global 
market [216]. Typical detection methods of neonicotinoids are based on enzyme linked immuno-sorbent assays (ELISA) [217,218], HPLC- or GC- mass spectrometry [219,220], surface plasmon resonance [221], and fluorescence spectroscopy [222], none of which are suitable for field analysis. Neonicotinoids are extremely effective against herbivorous insects [223], while having perceived low toxicity to mammals, birds and fish [224]. This has led to their widespread uptake for use on a variety of crops. However, concerns have been raised recently about environmental impact in affecting the homing capacity of honey bees, resulting in global colony collapse of the pollinator population [2,225]. Consequently, the European Union enforced a temporary ban (Dec 2013) [226] reducing the MRL of neonicotinoids to between 0.01 to $3 \mathrm{mg} / \mathrm{kg}$ for many fruits and vegetables [227,228].

Studies of detection of neonicotinoids are shown in Table 3. For example, Cao et al. synthesized three types of AuNP/MOF (metal-organic framework) composite to investigate the interaction between acetamiprid and the bridging molecules of the MOFs. Acetamiprid in this case was used to evaluate the characteristics of the SERS substrates. LODs of $0.02 \mu \mathrm{M}$, $0.009 \mu \mathrm{M}$, and $0.02 \mu \mathrm{M}$ were achieved for the three composites, which could satisfy the requirement of detection according to the MRLs of acetamiprid. [229] Yang et al. used SERS to evaluate the penetration behaviors of four pesticides (acetamiprid, thiabendazole, ferbam and phosmet) in a variety of fresh produce matrices. They used a pesticide/AgNP complex deposited onto the external surfaces of different fresh produce and measured the penetration depth of the complex using SERS [230]. Although the results are promising, this method requires complex sample preparation with the pesticide and AgNP, including washing steps, and is not ideal for farm-side analysis. On the other hand, Wijaya et al. employed silver dendrites for SERS-based detection of acetamiprid in apple juice and from swabs of the apple surface [231]. The TQ Analyst Software (Thermo Fisher Scientific) was used for SERS spectral data analysis, with second-derivative transformation employed to remove baseline and separate overlapped peaks. Outlier peaks were also removed to gain a more accurate quantification results. Acetamiprid detection was determined using principal component analysis (PCA) and retains the principal components (PCs) that capture the variation between sample treatments. This method does not need pre-treatment for the apple juice samples and the use of the swab is non-invasive to the fruit. This method therefore has the potential to be used for on-site pesticide detection.

Table 3. Neonicotinoids detection by SERS in food industry and environment monitoring.

\begin{tabular}{|c|c|c|c|c|c|}
\hline \multicolumn{2}{|c|}{ Neonicotinoids } & SERS Substrate & LOD (Reported) & $\begin{array}{c}\text { LOD } \\
\text { (Normalised) }\end{array}$ & $\begin{array}{c}\text { Excitation } \\
\text { Wavelength }\end{array}$ \\
\hline \multirow{4}{*}{ Acetamiprid } & Solvent [229] & $\begin{array}{c}\text { AuNP/MOF } \\
\text { (metal-organic } \\
\text { framework) composite }\end{array}$ & $0.009 \mu \mathrm{M}$ & $2 \mathrm{ppb}$ & $780 \mathrm{~nm}$ \\
\hline & apple juice [232] & $\begin{array}{c}\text { Gold nanoparticles } \\
\text { (AuNPs) bonded with } \\
\text { polyadenine } \\
\text { (polyA)-mediated aptamer } \\
\text { and Raman tag } \\
\text { (MMBN-AuNPs-aptamer) }\end{array}$ & $6.8 \mathrm{nM}$ & $1.514 \mathrm{ppb}$ & $532 \mathrm{~nm}$ \\
\hline & solvent [233] & $\begin{array}{c}\text { co-doped N/Ag carbon } \\
\text { dot }\end{array}$ & $0.006 \mu \mathrm{g} / \mathrm{L}$ & $6 \mathrm{ppt}$ & $633 \mathrm{~nm}$ \\
\hline & green tea [234] & $\mathrm{Au}$ NPs & $1.76 \times 10^{-8} \mathrm{M}$ & $3.91 \mathrm{ppb}$ & $\begin{array}{c}\text { micro-Raman } \\
\text { spectroscopy, } \\
785 \mathrm{~nm}\end{array}$ \\
\hline
\end{tabular}


Table 3. Cont.

\begin{tabular}{|c|c|c|c|c|c|}
\hline \multicolumn{2}{|c|}{ Neonicotinoids } & SERS Substrate & LOD (Reported) & $\begin{array}{c}\text { LOD } \\
\text { (Normalised) }\end{array}$ & $\begin{array}{c}\text { Excitation } \\
\text { Wavelength }\end{array}$ \\
\hline \multirow{6}{*}{ Imidacloprid } & solvent [235] & $\begin{array}{l}\text { 3-D Ag dendrites on Paper } \\
\text { substrate }\end{array}$ & $0.02811 \mathrm{ng} / \mathrm{mL}$ & $0.02811 \mathrm{ppb}$ & $633 \mathrm{~nm}$ \\
\hline & $\begin{array}{l}\text { extract solution } \\
\text { from apple [214] }\end{array}$ & Ag NP coated glass & $50 \mathrm{ng} / \mathrm{mL}$ & $50 \mathrm{ppb}$ & $633 \mathrm{~nm}$ \\
\hline & green tea [236] & $\begin{array}{c}\text { flower shaped Ag } \\
\text { nanostructure }\end{array}$ & $10^{-4} \mu \mathrm{g} / \mathrm{mL}$ & $10^{-4} \mathrm{ppm}$ & $785 \mathrm{~nm}$ \\
\hline & $\begin{array}{l}\text { waste water } \\
\text { treatment [237] }\end{array}$ & $\begin{array}{c}\text { r-GO supporting Ag } \\
\text { meso-flowers and } \\
\text { phenyl-modified graphitic } \\
\text { carbon nitride }\end{array}$ & $10 \mathrm{mg} / \mathrm{mL}$ & $10^{4} \mathrm{ppm}$ & $632.8 \mathrm{~nm}$ \\
\hline & Solvent [238] & $\begin{array}{c}\text { Ag nanostructures on } \\
\text { PVDF }\end{array}$ & $1 \mathrm{ng} / \mathrm{mL}$ & $1 \mathrm{ppb}$ & $514 \mathrm{~nm}$ \\
\hline & $\begin{array}{l}\text { fresh tea leaves; } \\
\text { apple peels [239] }\end{array}$ & $\mathrm{Au}$ NPs & $\begin{array}{l}0.5 \mathrm{mg} / \mathrm{kg} ; \\
0.02 \mathrm{mg} / \mathrm{kg}\end{array}$ & $\begin{array}{l}0.5 \mathrm{ppm} ; \\
0.02 \mathrm{ppm}\end{array}$ & $780 \mathrm{~nm}$ \\
\hline \multirow{2}{*}{ Thiamethoxam } & solvent [240] & Au NPs & $0.1 \mathrm{ng} / \mathrm{mL}$ & $0.1 \mathrm{ppb}$ & $785 \mathrm{~nm}$ \\
\hline & solvent [241] & Ag nano structure & $\mathrm{g} / \mathrm{mL}$ order & $10^{6} \mathrm{ppm}$ order & $532 \mathrm{~nm}$ \\
\hline Thiacloprid & fruit [242] & Au@Ag NPs & $0.1 \mathrm{mg} / \mathrm{kg}$ & $0.1 \mathrm{ppm}$ & $633 n$ \\
\hline
\end{tabular}

\subsection{Detection of Chemical Additives}

\subsubsection{Dye Molecules}

Dye molecules are used in industries to colour different materials such as silk, wool, cotton and paper. Unfortunately, the wasted water from these industries cause pollution in aquaculture and also cause serious toxic, carcinogenic and mutagenic effects in mammalian cells [243]. Besides, Malachite green and Crystal violet have been used for the treatment of fungal, parasitic and protozoan diseases in fish, and it is found to absorb and metabolise in tissues of fish [244]. The detection of dye molecules such as rhodamine 6G (R6G), malachite green, crystal violet (CV) and 4-aminobenzenthiol are the most reported chemical contaminants due to their ease of detection. These dye molecules are highly Raman active and used indiscriminately as antimicrobials in aquaculture. Moreover, the most significant and influential papers in this field have employed these dye molecules to study single molecular SERS detection [245], enhancement factors [37], and the mechanisms of SERS [246].

\subsubsection{Melamine}

In 2008, a sanitary scandal involved the intentional contamination of milk powder with melamine to give a false appearance of high protein levels [247]. Monitoring the level of residual melamine has since become important for the dairy industry. Regarding SERS, melamine is probably the most widely documented food adulterant, with Web of Science literature search revealing 309 articles up to 12 November 2021. The majority of melamine detection researches that employ SERS substrates are based on Au and Ag nanoparticle fabrication. Gold substrates include: Au colloids [248], Au NP agglomerates [249-251], 4-mercaptopyridine-modified Au NPs [252], and magnetic Au NPs [253], to name a few. Similarly the silver SERS substrates include: Ag Colloids [254], Ag NP agglomerates [255], Ag NP coated Ag/C nanospheres [256], Ag NP coated polystyrene nanospheres [144,257], cyclodextrin-coated Ag NPs [258], functional graphene/Ag nanocomposite [259].

Peng et al. used self-assembled vertical arrays of nanorods to detect melamine in methanol [260] and similarly, $\mathrm{Hu}$ et al. coated Ag nanoparticles on the surfaces of $\mathrm{Fe}_{3} \mathrm{O}_{4} @ \mathrm{SiO}_{2}$ composite microspheres to detect a melamine methanol solution [261]. Neither of these articles demonstrated melamine detection in real samples. Zhang et al. 
demonstrated melamine detection in milk using silver colloid solution. They reported on an easy pre-treatment for the milk, which, however, still required large instrumentation and, additionally, the colloid NPs required mixing with the diluted and filtered milk [246]. Alternatively, Guo et al. developed self-assembled hollow gold nanospheres to detect melamine in milk on a solid chip platform, which is ideal for remote sensing. However, they employed centrifugation as their only method of sample pre-treatment, which is complex and not suitable for transporting [262].

Another novel method by Betz et al. used a copper tape and a penny coin to fabricate Ag micro- and nanostructures. It was used to analyse infant formula adulterated with melamine [255]. The fact that these substrates form in five minutes on-site without the need for complex equipment, sample pre-treatment, or harsh chemicals enabled the possibility of remote point-of-sampling. However, their LOD (5 ppm) is not sufficient for remote melamine detection.

Finally, Chen et al. reported on the detection of melamine in egg white using fabricated $\mathrm{ZnO} / \mathrm{Au}$ composite nanoneedle arrays, see Figure 6. The results showed some background interferences from the egg proteins but the characteristic peak for melamine at $\sim 682 \mathrm{~cm}^{-1}$ remained detectable and was well resolved [263]. The only sample preparation is a filtering of the egg solution through four layers of gauge, which can easily be employed on-site as it requires no complex instrumentation. Similarly, Kim et al. applied their previously reported gold nanofingers to melamine detection in milk [264]. Although they also require sample pre-treatment, the authors avoid using centrifugation, as it is neither portable nor low cost. Instead, they employ a mini dialysis kit and detect characteristic melamine peaks from the dialysis filtered solutions at $1 \mathrm{ppm}$. They also demonstrate melamine detection at $100 \mathrm{ppb}$ in infant formula using a solution gel filtration chromatography treatment. These are a few articles that report SERS substrates and methods of sample pre-treatment, that both are fully compatible for field applications in a limited-resource environment.

(a)

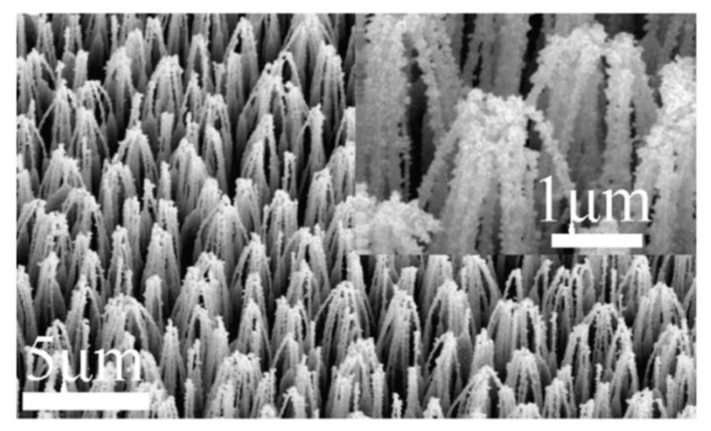

(b)

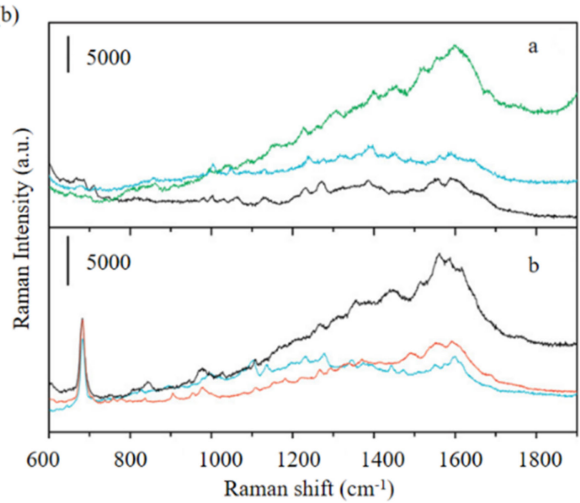

Figure 6. (a) SEM image of $\mathrm{ZnO} / \mathrm{Au}$ composite nanoneedle arrays; (b) SERS spectra of egg white solution (6 g/L) (a) and the melamine-tainted egg white solution $(\mathbf{b})$ on $\mathrm{ZnO} / \mathrm{Au}$ nanoneedles. The concentration of melamine and egg white in the mixture is $1.0 \times 10^{-5} \mathrm{M}$ and about $6 \mathrm{~g} / \mathrm{L}$, by Chen et al. [263].

\section{Conclusions and Perspective}

In this review paper, SERS as a useful technology for Agri-Food and environmental sensing has been investigated. Compared to other detecting technologies such as chromatography or electrochemical based methods, SERS has the potential to deliver rapid, ultra-sensitive and highly specific detections of a wide range of chemicals and biomolecules. SERS substrates fabrication methods include bottom-up and top-down. Bottom-up approaches refer to the fabrication of nanostructures by chemical synthesis, colloid aggregation, electrochemical deposition and self-assembly; top-down methods include lithography techniques (electron-beam (E-beam) and nanoimprint lithography, laser etching together with metal film deposition (sputtering, metal evaporation, atomic layer deposition), templating (e.g., anodic aluminium oxide), inkjet printing, etc. The 
combination of top-down and bottom-up methods could improve SERS intensity. The common plasmonic materials are $\mathrm{Ag}, \mathrm{Cu}, \mathrm{Au}$ or their composite material. A wide choice of the support substrate is variable $\mathrm{Si}, \mathrm{Cu}$, tissue, paper, leaves and aluminium cans, etc. SERS related devices could widely be used in agri-food and environment monitoring, following the SERS device fabrication method section; this review paper presents SERS applications in detection of pesticides such as organophosphate (OP) insecticides and neonicotinoids insecticides as well as illegal food additive such as dyes and melamine.

However, despite the advancement and strategies presented above, some challenges still need to be overcome for SERS to be widely used in agri-food and environment analytical applications. These include (i) repeatability of SERS substrates and SERS signals for each Raman measurements; (ii) weak interaction-or even repulsion because of the surface energy - between some analytes and SERS surface; (iii) stability of SERS substrate and functional layers that can in some instance react with the targeted analytes or degrade over time (e.g., oxidation) or under continuous laser excitation; (iv) general non suitability for direct detection of heavy metal or macromolecular such as protein; (v) current lack of standardised optical setup or methodologies to compare results obtained by different research groups and (vi) in real sample verification, SERS devices performance could be affected by contamination or interferences from the environment.

Regarding sample reproducibility, SERS substrates could benefit from constant advances in nanofabrication processes and instrumentation as well as in surface chemistry. Regarding quantification, techniques such as isotope labelling [265] or standard addition method have proven promising. Also, new emerging techniques such as electrochemical SERS (EC-SERS), shifted excitation Raman difference spectroscopy (SERDS) or surface enhanced spatially offset resonance Raman spectroscopy (SESORRS) such could help overcome the limitations mentioned above.

All in all, SERS devices benefit from a wide range of choice of plasmonic structures such as $\mathrm{Ag} / \mathrm{Au}$ NPs, nano rods, nano flowers, nano cubes, and their composite materials etc; supporting substrate, fabrication method and functionalization method. Besides, they also have a numerous of advantages such as rapid response time, high sensitivity and selectivity and possibility to use handheld devices for onsite measurements. However, several challenges still exist in terms of reliability and durability for SERS sensing platform. Ongoing advances in nanofabrication and chemistry have the potential to overcome the current limitations of SERS sensing. As a result, we believe that SERS will soon be a widespread analytical technique for sensitive detection of contaminants in agri-food and environmental applications.

Author Contributions: Conceptualization, Y.Y. and N.C.; data curation, Y.Y. and N.C.; writingoriginal draft preparation, Y.Y. and N.C.; writing-review and editing, A.O. and P.L.; visualization, Y.Y. and N.C.; supervision, A.O. and P.L.; project administration, A.O. and P.L.; funding acquisition, A.O. and P.L. All authors have read and agreed to the published version of the manuscript.

Funding: This research was funded by the European Union's Horizon 2020 research and innovation programme under the Marie Skłodowska-Curie grant agreement No: H2020-MSCA-ITN-2018-813680 as well as the Irish EPA UisceSense Project (Code: 2015-W-MS-21) and the VistaMilk Center Science Foundation Ireland (SFI) and Department of Agriculture Food and the Marine (DAFM) under Grant Number $16 / \mathrm{RC} / / 3835$.

Institutional Review Board Statement: Not applicable.

Informed Consent Statement: Not applicable.

Conflicts of Interest: The authors declare no conflict of interest.

\section{References}

1. Food Agriculture Organization. The Future of Food and Agriculture-Trends and Challenges; United Nations: Rome, Italy, 2017.

2. Henry, M.; Beguin, M.; Requier, F.; Rollin, O.; Odoux, J.-F.; Aupinel, P.; Aptel, J.; Tchamitchian, S.; Decourtye, A. A common pesticide decreases foraging success and survival in honey bees. Science 2012, 336, 348-350. [CrossRef] 
3. Gong, T.X.; Huang, Y.F.; Wei, Z.J.; Huang, W.; Wei, X.B.; Zhang, X.S. Magnetic assembled 3D SERS substrate for sensitive detection of pesticide residue in soil. Nanotechnology 2020, 31, 205501. [CrossRef]

4. Guselnikova, O.; Postnikov, P.; Elashnikov, R.; Miliutina, E.; Svorcik, V.; Lyutakov, O. Metal-organic framework (MOF-5) coated SERS active gold gratings: A platform for the selective detection of organic contaminants in soil. Anal. Chim. Acta 2019, 1068, 70-79. [CrossRef]

5. Krafft, B.; Tycova, A.; Urban, R.D.; Dusny, C.; Belder, D. Microfluidic device for concentration and SERS-based detection of bacteria in drinking water. Electrophoresis 2021, 42, 86-94. [CrossRef] [PubMed]

6. Zhu, C.H.; Zhao, Q.S.; Meng, G.W.; Wang, X.J.; Hu, X.Y.; Han, F.M.; Lei, Y. Silver nanoparticle-assembled micro-bowl arrays for sensitive SERS detection of pesticide residue. Nanotechnology 2020, 31, 126300. [CrossRef] [PubMed]

7. Wang, K.; Sun, D.-W.; Pu, H.; Wei, Q. Polymer multilayers enabled stable and flexible Au@Ag nanoparticle array for nondestructive SERS detection of pesticide residues. Talanta 2021, 223, 205303. [CrossRef] [PubMed]

8. Grubisha, D.S.; Lipert, R.J.; Park, H.-Y.; Driskell, J.; Porter, M.D. Femtomolar Detection of Prostate-Specific Antigen: An Immunoassay Based on Surface-Enhanced Raman Scattering and Immunogold Labels. Anal. Chem. 2003, 75, 5936-5943. [CrossRef] [PubMed]

9. Fan, M.; Andrade, G.F.S.; Brolo, A.G. A review on the fabrication of substrates for surface enhanced Raman spectroscopy and their applications in analytical chemistry. Anal. Chim. Acta 2011, 693, 7-25. [CrossRef] [PubMed]

10. Justin, L.A.; Jeremy, D.D.; Ralph, A.T.; Yiping, Z. Current Progress on Surface-Enhanced Raman Scattering Chemical/Biological Sensing. In Functional Nanoparticles for Bioanalysis, Nanomedicine, and Bioelectronic Devices Volume 2; American Chemical Society: Washington, DC, USA, 2012; Volume 1113, pp. 235-272.

11. Xie, W.; Schlucker, S. Medical applications of surface-enhanced Raman scattering. Phys. Chem. Chem. Phys. 2013, 15, 5329-5344. [CrossRef]

12. Willets, K.A. Probing nanoscale interfaces with electrochemical surface-enhanced Raman scattering. Curr. Opin. Electrochem. 2019, 13, 18-24. [CrossRef]

13. Craig, A.P.; Franca, A.S.; Irudayaraj, J. Surface-Enhanced Raman Spectroscopy Applied to Food Safety. Annu. Rev. Food Sci. Technol. 2013, 4, 369-380. [CrossRef]

14. Fan, C.; Hu, Z.Q.; Mustapha, A.; Lin, M.S. Rapid detection of food- and waterborne bacteria using surface-enhanced Raman spectroscopy coupled with silver nanosubstrates. Appl. Microbiol. Biotechnol. 2011, 92, 1053-1061. [CrossRef]

15. Zhang, Y.; Huang, Y.; Zhai, F.; Du, R.; Liu, Y.; Lai, K. Analyses of enrofloxacin, furazolidone and malachite green in fish products with surface-enhanced Raman spectroscopy. Food Chem. 2012, 135, 845-850. [CrossRef] [PubMed]

16. Cialla, D.; Marz, A.; Bohme, R.; Theil, F.; Weber, K.; Schmitt, M.; Popp, J. Surface-enhanced Raman spectroscopy (SERS): Progress and trends. Anal. Bioanal. Chem. 2012, 403, 27-54. [CrossRef]

17. Granger, J.H.; Schlotter, N.E.; Crawford, A.C.; Porter, M.D. Prospects for point-of-care pathogen diagnostics using surfaceenhanced Raman scattering (SERS). Chem. Soc. Rev. 2016, 45, 3865-3882. [CrossRef] [PubMed]

18. Jarvis, R.M.; Goodacre, R. Characterisation and identification of bacteria using SERS. Chem. Soc. Rev. 2008, 37, 931-936. [CrossRef] [PubMed]

19. Laserna, J. Modern Techniques in Raman Spectroscopy; John Wiley and Sons: New York, NY, USA, 1996.

20. Wen, P.; Yang, F.; Ge, C.; Li, S.; Xu, Y.; Chen, L. Self-assembled nano-Ag/Au@Au film composite SERS substrates show high uniformity and high enhancement factor for creatinine detection. Nanotechnology 2021, 32, 395502. [CrossRef]

21. Kalantar-zadeh, K.; Fry, B. Nanotechnology-Enabled Sensors; Springer Science \& Business Media: Berlin/Heidelberg, Germany, 2007.

22. Settle, F.A. Handbook of Instrumental Techniques for Analytical Chemistry; Prentice Hall PTR: Hoboken, NJ, USA, 1997.

23. Gardiner, D.J. Practical Raman Spectroscopy; Spinger: Berlin/Heidelberg, Germany, 1989.

24. Jablonski, A. Efficiency of anti-Stokes fluorescence in dyes. Nature 1933, 131, 839-840. [CrossRef]

25. Fleischmann, M.; Hendra, P.J.; McQuillan, A.J. Raman spectra of pyridine adsorbed at a silver electrode. Chem. Phys. Lett. 1974, 26, 163-166. [CrossRef]

26. Gersten, J.I. The effect of surface roughness on surface enhanced Raman scattering. J. Chem. Phys. 1980, 72, 5779-5780. [CrossRef]

27. Gersten, J.; Nitzan, A. Electromagnetic theory of enhanced Raman scattering by molecules adsorbed on rough surfaces. J. Chem. Phys. 1980, 73, 3023-3037. [CrossRef]

28. Moskovits, M. Surface-enhanced spectroscopy. Rev. Mod. Phys. 1985, 57, 783-826. [CrossRef]

29. Otto, A.; Mrozek, I.; Grabhorn, H.; Akemann, W. Surface-enhanced Raman scattering. J. Phys. Condens. Matter 1992, 4, 1143. [CrossRef]

30. Stiles, P.L.; Dieringer, J.A.; Shah, N.C.; Duyne, R.P.V. Surface-Enhanced Raman Spectroscopy. Annu. Rev. Anal. Chem. 2008, 1, 601-626. [CrossRef]

31. Hutter, E.; Fendler, J.H. Exploitation of Localized Surface Plasmon Resonance. Adv. Mater. 2004, 16, 1685-1706. [CrossRef]

32. Camden, J.P.; Dieringer, J.A.; Wang, Y.; Masiello, D.J.; Marks, L.D.; Schatz, G.C.; Van Duyne, R.P. Probing the Structure of Single-Molecule Surface-Enhanced Raman Scattering Hot Spots. J. Am. Chem. Soc. 2008, 130, 12616-12617. [CrossRef]

33. Sun, M.; Wan, S.; Liu, Y.; Jia, Y.; Xu, H. Chemical mechanism of surface-enhanced resonance Raman scattering via charge transfer in pyridine-Ag2 complex. J. Raman Spectrosc. 2008, 39, 402-408. [CrossRef]

34. Adrian, F.J. Charge transfer effects in surface-enhanced Raman scatteringa. J. Chem. Phys. 1982, 77, 5302-5314. [CrossRef] 
35. Schatz, G.C. Theoretical studies of surface enhanced Raman scattering. Acc. Chem. Res. 1984, 17, 370-376. [CrossRef]

36. Campion, A.; Ivanecky, J., III; Child, C.; Foster, M. On the mechanism of chemical enhancement in surface-enhanced Raman scattering. J. Am. Chem. Soc. 1995, 117, 11807-11808. [CrossRef]

37. Le Ru, E.C.; Blackie, E.; Meyer, M.; Etchegoin, P.G. Surface Enhanced Raman Scattering Enhancement Factors: A Comprehensive Study. J. Phys. Chem. C 2007, 111, 13794-13803. [CrossRef]

38. Weaver, M.J.; Zou, S.; Chan, H.Y.H. Peer Reviewed: The New Interfacial Ubiquity of Surface-Enhanced Raman Spectroscopy. Anal. Chem. 2000, 72, 38A-47A. [CrossRef]

39. Etchegoin, P.G.; Le Ru, E.C. A perspective on single molecule SERS: Current status and future challenges. Phys. Chem. Chem. Phys. 2008, 10, 6079-6089. [CrossRef] [PubMed]

40. Park, W.H.; Kim, Z.H. Charge Transfer Enhancement in the SERS of a Single Molecule. Nano Lett. 2010, 10, 4040-4048. [CrossRef]

41. Bell, S.E.; McCourt, M.R. SERS enhancement by aggregated Au colloids: Effect of particle size. Phys. Chem. Chem. Phys. 2009, 11, 7455-7462. [CrossRef]

42. Lee, S.J.; Guan, Z.; Xu, H.; Moskovits, M. Surface-Enhanced Raman Spectroscopy and Nanogeometry: The Plasmonic Origin of SERS. J. Phys. Chem. C 2007, 111, 17985-17988. [CrossRef]

43. Lancaster, C.A.; Scholl, W.E.; Ticknor, M.A.; Shumaker-Parry, J.S. Uniting Top-Down and Bottom-Up Strategies Using Fabricated Nanostructures as Hosts for Synthesis of Nanomites. J. Phys. Chem. C 2020, 124, 6822-6829. [CrossRef]

44. Banholzer, M.J.; Millstone, J.E.; Qin, L.; Mirkin, C.A. Rationally designed nanostructures for surface-enhanced Raman spectroscopy. Chem. Soc. Rev. 2008, 37, 885-897. [CrossRef]

45. Pan, X.-T.; Liu, Y.-Y.; Qian, S.-Q.; Yang, J.-M.; Li, Y.; Gao, J.; Liu, C.-G.; Wang, K.; Xia, X.-H. Free-Standing Single Ag Nanowires for Multifunctional Optical Probes. ACS Appl. Mater. Interfaces 2021, 13, 19023-19030. [CrossRef] [PubMed]

46. Xu, K.-X.; Chen, X.; Huang, Z.; Chen, Z.-N.; Chen, J.; Sun, J.-J.; Fang, Y.; Li, J.-F. Ligand-Free Fabrication of Ag Nanoassemblies for Highly Sensitive and Reproducible Surface-Enhanced Raman Scattering Sensing of Antibiotics. ACS Appl. Mater. Interfaces 2021, 13, 1766-1772. [CrossRef]

47. Choi, S.; Jeong, H.; Choi, K.H.; Song, J.Y.; Kim, J. Electrodeposition of triangular Pd rod nanostructures and their electrocatalytic and SERS activities. ACS Appl. Mater. Interfaces 2014, 6, 3002-3007. [CrossRef]

48. Ge, D.; Wei, J.; Ding, J.; Zhang, J.; Ma, C.; Wang, M.; Zhang, L.; Zhu, S. Silver Nano-Dendrite-Plated Porous Silicon Substrates Formed by Single-Step Electrochemical Synthesis for Surface-Enhanced Raman Scattering. ACS Appl. Nano Mater. 2020, 3 , 3011-3018. [CrossRef]

49. Jeong, H.; Kim, J. Electrodeposition of nanoflake Pd structures: Structure-dependent wettability and SERS activity. ACS Appl. Mater. Interfaces 2015, 7, 7129-7135. [CrossRef]

50. Raveendran, J.; Stamplecoskie, K.G.; Docoslis, A. Tunable Fractal Nanostructures for Surface-Enhanced Raman Scattering via Templated Electrodeposition of Silver on Low-Energy Surfaces. ACS Appl. Nano Mater. 2020, 3, 2665-2679. [CrossRef]

51. Longoni, M.; Zalaffi, M.S.; de Ferri, L.; Stortini, A.M.; Pojana, G.; Ugo, P. Surface Enhanced Raman Spectroscopy With Electrodeposited Copper Ultramicro-Wires With/Without Silver Nanostars Decoration. Nanomaterials 2021, 11, 518. [CrossRef]

52. Grzelczak, M.; Vermant, J.; Furst, E.M.; Liz-Marzán, L.M. Directed Self-Assembly of Nanoparticles. ACS Nano 2010, 4, $3591-3605$. [CrossRef] [PubMed]

53. Zhu, S.; Fan, C.; Wang, J.; He, J.; Liang, E. Self-assembled Ag nanoparticles for surface enhanced Raman scattering. Opt. Rev. 2013, 20, 361-366. [CrossRef]

54. Gao, T.; Wang, Y.; Wang, K.; Zhang, X.; Dui, J.; Li, G.; Lou, S.; Zhou, S. Controlled synthesis of homogeneous Ag nanosheetassembled film for effective SERS substrate. ACS Appl. Mater. Interfaces 2013, 5, 7308-7314. [CrossRef]

55. Zhang, L. Self-assembly Ag nanoparticle monolayer film as SERS Substrate for pesticide detection. Appl. Surf. Sci. 2013, 270, 292-294. [CrossRef]

56. Wu, Y.; Dang, H.; Park, S.-G.; Chen, L.; Choo, J. SERS-PCR assays of SARS-CoV-2 target genes using Au nanoparticles-internalized Au nanodimple substrates. Biosens. Bioelectron. 2022, 197, 113736. [CrossRef] [PubMed]

57. Lee, S.J.; Morrill, A.R.; Moskovits, M. Hot Spots in Silver Nanowire Bundles for Surface-Enhanced Raman Spectroscopy. J. Am. Chem. Soc. 2006, 128, 2200-2201. [CrossRef]

58. Zheng, G.; Patolsky, F.; Cui, Y.; Wang, W.U.; Lieber, C.M. Multiplexed electrical detection of cancer markers with nanowire sensor arrays. Nat. Biotechnol. 2005, 23, 1294-1301. [CrossRef] [PubMed]

59. Tang, J.; Zhao, Q.; Zhang, N.; Man, S.-Q. Facile fabrication of large-area and uniform silica nanospheres monolayer for efficient surface-enhanced Raman scattering. Appl. Surf. Sci. 2014, 308, 247-252. [CrossRef]

60. Li, W.; Camargo, P.H.C.; Lu, X.; Xia, Y. Dimers of Silver Nanospheres: Facile Synthesis and Their Use as Hot Spots for SurfaceEnhanced Raman Scattering. Nano Lett. 2009, 9, 485-490. [CrossRef] [PubMed]

61. Martín, A.; Pescaglini, A.; Schopf, C.; Scardaci, V.; Coull, R.; Byrne, L.; Iacopino, D. Surface-Enhanced Raman Scattering of 4-Aminobenzenethiol on Au Nanorod Ordered Arrays. J. Phys. Chem. C 2014, 118, 13260-13267. [CrossRef]

62. Martin, A.; Wang, J.J.; Iacopino, D. Flexible SERS active substrates from ordered vertical Au nanorod arrays. RSC Adv. 2014, 4, 20038-20043. [CrossRef]

63. Xie, Z.; Tao, J.; Lu, Y.; Lin, K.; Yan, J.; Wang, P.; Ming, H. Polymer optical fiber SERS sensor with gold nanorods. Opt. Commun. 2009, 282, 439-442. [CrossRef] 
64. Oh, M.K.; Shin, Y.S.; Lee, C.L.; De, R.; Kang, H.; Yu, N.E.; Kim, B.H.; Kim, J.H.; Yang, J.K. Morphological and SERS Properties of Silver Nanorod Array Films Fabricated by Oblique Thermal Evaporation at Various Substrate Temperatures. Nanoscale Res. Lett. 2015, 10, 962. [CrossRef]

65. Lovera, P.; Creedon, N.; Alatawi, H.; Mitchell, M.; Burke, M.; Quinn, A.J.; O’Riordan, A. Low-cost silver capped polystyrene nanotube arrays as super-hydrophobic substrates for SERS applications. Nanotechnology 2014, 25, 175502. [CrossRef]

66. Lovera, P.; Creedon, N.; Alatawi, H.; O'Riordan, A. Metal Capped Polystyrene Nanotubes Arrays as Super-Hydrophobic Substrates for SERS Applications; SPIE: Washington, DC, USA, 2014; Volume 9129.

67. Walker, D.A.; Browne, K.P.; Kowalczyk, B.; Grzybowski, B.A. Self-Assembly of Nanotriangle Superlattices Facilitated by Repulsive Electrostatic Interactions. Angew. Chem. Int. Ed. 2010, 49, 6760-6763. [CrossRef]

68. Kumar-Krishnan, S.; Esparza, R.; Pal, U. Controlled Fabrication of Flower-Shaped Au-Cu Nanostructures Using a Deep Eutectic Solvent and Their Performance in Surface-Enhanced Raman Scattering-Based Molecular Sensing. ACS Omega 2020, 5, 3699-3708. [CrossRef]

69. Liu, Z.; Yang, Z.; Peng, B.; Cao, C.; Zhang, C.; You, H.; Xiong, Q.; Li, Z.; Fang, J. Highly Sensitive, Uniform, and Reproducible Surface-Enhanced Raman Spectroscopy from Hollow Au-Ag Alloy Nanourchins. Adv. Mater. 2014, 26, 2431-2439. [CrossRef]

70. Yang, M.; Alvarez-Puebla, R.; Kim, H.-S.; Aldeanueva-Potel, P.; Liz-Marzán, L.M.; Kotov, N.A. SERS-Active Gold Lace Nanoshells with Built-in Hotspots. Nano Lett. 2010, 10, 4013-4019. [CrossRef]

71. Barbillon, G. Applications of Shell-Isolated Nanoparticle-Enhanced Raman Spectroscopy. Photonics 2021, 8, 46. [CrossRef]

72. Barbillon, G.; Ivanov, A.; Sarychev, A.K. Hybrid Au/Si Disk-Shaped Nanoresonators on Gold Film for Amplified SERS Chemical Sensing. Nanomaterials 2019, 9, 1588. [CrossRef]

73. Vigderman, L.; Zubarev, E.R. Starfruit-Shaped Gold Nanorods and Nanowires: Synthesis and SERS Characterization. Langmuir 2012, 28, 9034-9040. [CrossRef] [PubMed]

74. Li, H.; Wang, Y.; Li, Y.; Zhang, J.; Qiao, Y.; Wang, Q.; Che, G. Fabrication of pollutant-resistance SERS imprinted sensors based on SiO2@TiO2@Ag composites for selective detection of pyrethroids in water. J. Phys. Chem. Solids 2020, 138, 109254. [CrossRef]

75. Krishnan, S.K.; Chipatecua Godoy, Y. Deep Eutectic Solvent-Assisted Synthesis of Au Nanostars Supported on Graphene Oxide as an Efficient Substrate for SERS-Based Molecular Sensing. ACS Omega 2020, 5, 1384-1393. [CrossRef] [PubMed]

76. Zhu, C.; Meng, G.; Huang, Q.; Huang, Z.; Chu, Z. Au Hierarchical Micro/Nanotower Arrays and Their Improved SERS Effect by Ag Nanoparticle Decoration. Cryst. Growth Des. 2011, 11, 748-752. [CrossRef]

77. Subramanian, B.; Theriault, G.; Robichaud, J.; Tchoukanova, N.; Djaoued, Y. Large-area crack-free Au-SiO2 2D inverse opal composite films: Fabrication and SERS applications. Mater. Chem. Phys. 2020, 244, 122630. [CrossRef]

78. Barbillon, G. Latest Novelties on Plasmonic and Non-Plasmonic Nanomaterials for SERS Sensing. Nanomaterials 2020, 10, 1200. [CrossRef]

79. Sun, Y.; Xia, Y. Shape-controlled synthesis of gold and silver nanoparticles. Science 2002, 298, 2176-2179. [CrossRef]

80. Chen, J.; McLellan, J.M.; Siekkinen, A.; Xiong, Y.; Li, Z.-Y.; Xia, Y. Facile Synthesis of Gold-Silver Nanocages with Controllable Pores on the Surface. J. Am. Chem. Soc. 2006, 128, 14776-14777. [CrossRef] [PubMed]

81. Ye, J.; Van Dorpe, P.; Van Roy, W.; Borghs, G.; Maes, G. Fabrication, Characterization, and Optical Properties of Gold Nanobowl Submonolayer Structures. Langmuir 2009, 25, 1822-1827. [CrossRef] [PubMed]

82. Liebig, F.; Sarhan, R.M.; Sander, M.; Koopman, W.; Schuetz, R.; Bargheer, M.; Koetz, J. Deposition of Gold Nanotriangles in Large Scale Close-Packed Monolayers for X-ray-Based Temperature Calibration and SERS Monitoring of Plasmon-Driven Catalytic Reactions. ACS Appl. Mater. Interfaces 2017, 9, 20247-20253. [CrossRef]

83. Li, C.; Shuford, K.L.; Chen, M.; Lee, E.J.; Cho, S.O. A Facile Polyol Route to Uniform Gold Octahedra with Tailorable Size and Their Optical Properties. ACS Nano 2008, 2, 1760-1769. [CrossRef]

84. Nguyen, P.-D.; Zhang, X.; Su, J. One-Step Controlled Synthesis of Size-Tunable Toroidal Gold Particles for Biochemical Sensing. ACS Appl. Nano Mater. 2019, 2, 7839-7847. [CrossRef]

85. Qiu, Y.H.; Ding, S.J.; Lin, Y.J.; Chen, K.; Yang, D.J.; Ma, S.; Li, X.; Lin, H.Q.; Wang, J.; Wang, Q.Q. Growth of Au Hollow Stars and Harmonic Excitation Energy Transfer. ACS Nano 2020, 14, 736-745. [CrossRef] [PubMed]

86. Maier, S.A.; Brongersma, M.L.; Kik, P.G.; Meltzer, S.; Requicha, A.A.; Atwater, H.A. Plasmonics-A route to nanoscale optical devices. Adv. Mater. 2001, 13, 1501-1505. [CrossRef]

87. Alvarez-Puebla, R.; Liz-Marzán, L.M.; García de Abajo, F.J. Light Concentration at the Nanometer Scale. J. Phys. Chem. Lett. 2010, 1, 2428-2434. [CrossRef]

88. Aroca, R.; Alvarez-Puebla, R.; Pieczonka, N.; Sanchez-Cortez, S.; Garcia-Ramos, J. Surface-enhanced Raman scattering on colloidal nanostructures. Adv. Colloid Interface Sci. 2005, 116, 45-61. [CrossRef]

89. Lee, P.C.; Meisel, D. Adsorption and surface-enhanced Raman of dyes on silver and gold sols. J. Phys. Chem. 1982, 86, 3391-3395. [CrossRef]

90. Rivas, L.; Sanchez-Cortes, S.; García-Ramos, J.V.; Morcillo, G. Mixed Silver/Gold Colloids: A Study of Their Formation, Morphology, and Surface-Enhanced Raman Activity. Langmuir 2000, 16, 9722-9728. [CrossRef]

91. Faulds, K.; Littleford, R.E.; Graham, D.; Dent, G.; Smith, W.E. Comparison of Surface-Enhanced Resonance Raman Scattering from Unaggregated and Aggregated Nanoparticles. Anal. Chem. 2004, 76, 592-598. [CrossRef] [PubMed] 
92. Schopf, C.; Martín, A.; Burke, M.; Jones, D.; Pescaglini, A.; O’Riordan, A.; Quinn, A.J.; Iacopino, D. Au nanorod plasmonic superstructures obtained by a combined droplet evaporation and stamping method. J. Mater. Chem. C 2014, 2, 3536-3541. [CrossRef]

93. Yang, J.K.; Kang, H.; Lee, H.; Jo, A.; Jeong, S.; Jeon, S.J.; Kim, H.I.; Lee, H.Y.; Jeong, D.H.; Kim, J.H.; et al. Single-Step and Rapid Growth of Silver Nanoshells as SERS-Active Nanostructures for Label-Free Detection of Pesticides. ACS Appl. Mater. Interfaces 2014, 6, 12541-12549. [CrossRef] [PubMed]

94. Aroca, R.F.; Goulet, P.J.G.; dos Santos, D.S.; Alvarez-Puebla, R.A.; Oliveira, O.N. Silver Nanowire Layer-by-Layer Films as Substrates for Surface-Enhanced Raman Scattering. Anal. Chem. 2005, 77, 378-382. [CrossRef]

95. Freeman, R.G.; Grabar, K.C.; Allison, K.J.; Bright, R.M.; Davis, J.A.; Guthrie, A.P.; Hommer, M.B.; Jackson, M.A.; Smith, P.C.; Walter, D.G.; et al. Self-assembled metal colloid monolayers: An approach to SERS substrates. Science 1995, 267, 1629-1632. [CrossRef] [PubMed]

96. Wang, Z.; Pan, S.; Krauss, T.D.; Du, H.; Rothberg, L.J. The structural basis for giant enhancement enabling single-molecule Raman scattering. Proc. Natl. Acad. Sci. USA 2003, 100, 8638-8643. [CrossRef]

97. Fan, M.; Brolo, A.G. Silver nanoparticles self assembly as SERS substrates with near single molecule detection limit. Phys. Chem. Chem. Phys. 2009, 11, 7381-7389. [CrossRef]

98. Yu, W.W.; White, I.M. A simple filter-based approach to surface enhanced Raman spectroscopy for trace chemical detection. Analyst 2012, 137, 1168-1173. [CrossRef] [PubMed]

99. Shiohara, A.; Langer, J.; Polavarapu, L.; Liz-Marzan, L.M. Solution processed polydimethylsiloxane/gold nanostar flexible substrates for plasmonic sensing. Nanoscale 2014, 6, 9817-9823. [CrossRef]

100. Polavarapu, L.; La Porta, A.; Novikov, S.M.; Coronado-Puchau, M.; Liz-Marzan, L.M. Pen-on-Paper Approach Toward the Design of Universal Surface Enhanced Raman Scattering Substrates. Small 2014, 10, 3065-3071. [CrossRef] [PubMed]

101. Lee, C.H.; Tian, L.; Singamaneni, S. Paper-based SERS swab for rapid trace detection on real-world surfaces. ACS Appl. Mater. Interfaces 2010, 2, 3429-3435. [CrossRef] [PubMed]

102. Chen, J.; Huang, Y.; Kannan, P.; Zhang, L.; Lin, Z.; Zhang, J.; Chen, T.; Guo, L. Flexible and Adhesive Surface Enhance Raman Scattering Active Tape for Rapid Detection of Pesticide Residues in Fruits and Vegetables. Anal. Chem. 2016, 88, 2149-2155. [CrossRef]

103. Kahl, M.; Voges, E.; Kostrewa, S.; Viets, C.; Hill, W. Periodically structured metallic substrates for SERS. Sens. Actuators B Chem. 1998, 51, 285-291. [CrossRef]

104. Yu, Q.; Guan, P.; Qin, D.; Golden, G.; Wallace, P.M. Inverted Size-Dependence of Surface-Enhanced Raman Scattering on Gold Nanohole and Nanodisk Arrays. Nano Lett. 2008, 8, 1923-1928. [CrossRef]

105. Wu, T.; Lin, Y.-W. Surface-enhanced Raman scattering active gold nanoparticle/nanohole arrays fabricated through electron beam lithography. Appl. Surf. Sci. 2018, 435, 1143-1149. [CrossRef]

106. Krishnamoorthy, S.; Krishnan, S.; Thoniyot, P.; Low, H.Y. Inherently Reproducible Fabrication of Plasmonic Nanoparticle Arrays for SERS by Combining Nanoimprint and Copolymer Lithography. ACS Appl. Mater. Interfaces 2011, 3, 1033-1040. [CrossRef]

107. Robinson, C.; Justice, J.; Petäjä, J.; Karppinen, M.; Corbett, B.; O’Riordan, A.; Lovera, P. Nanoimprint Lithography-Based Fabrication of Plasmonic Array of Elliptical Nanoholes for Dual-Wavelength, Dual-Polarisation Refractive Index Sensing. Plasmonics 2019, 14, 951-959. [CrossRef]

108. Yang, J.; Li, J.; Du, Z.; Teng, J.; Hong, M. Laser Hybrid Micro/nano-structuring of Si Surfaces in Air and its Applications for SERS Detection. Sci. Rep. 2014, 4, 6657. [CrossRef] [PubMed]

109. Sun, W.; Hong, R.; Liu, Q.; Li, Z.; Shi, J.; Tao, C.; Zhang, D. SERS-active Ag-Al alloy nanoparticles with tunable surface plasmon resonance induced by laser ablation. Opt. Mater. 2019, 96, 109298. [CrossRef]

110. Bian, X.; Xu, J.; Yang, J.; Chiu, K.-L.; Jiang, S. Flexible Ag SERS substrate for non-destructive and rapid detection of toxic materials on irregular surface. Surf. Interfaces 2021, 23, 100995. [CrossRef]

111. Zhou, Q.; Thokchom, A.K.; Kim, D.-J.; Kim, T. Inkjet-printed Ag micro-/nanostructure clusters on Cu substrates for in-situ pre-concentration and surface-enhanced Raman scattering. Sens. Actuators B Chem. 2017, 243, 176-183. [CrossRef]

112. Huebner, U.; Boucher, R.; Schneidewind, H.; Cialla, D.; Popp, J. Microfabricated SERS-arrays with sharp-edged metallic nanostructures. Microelectron. Eng. 2008, 85, 1792-1794. [CrossRef]

113. Yang, J.-Y.; Park, S.-G.; Jung, S.; Byeon, E.-Y.; Kim, D.-G.; Jung, H.S.; Kim, H.J.; Lee, S. SERS substrates based on self-organized dimple nanostructures on polyethylene naphthalate films produced via oxygen ion beam sputtering. Appl. Surf. Sci. 2022, 572, 151452. [CrossRef]

114. Muhammad, M.; Shao, C.-S.; Huang, Q. Aptamer-functionalized Au nanoparticles array as the effective SERS biosensor for label-free detection of interleukin-6 in serum. Sens. Actuators B Chem. 2021, 334, 129607. [CrossRef]

115. Zhang, C.; Yi, P.; Peng, L.; Lai, X.; Chen, J.; Huang, M.; Ni, J. Continuous fabrication of nanostructure arrays for flexible surface enhanced Raman scattering substrate. Sci. Rep. 2017, 7, 39814. [CrossRef] [PubMed]

116. Shi, G.; Wang, M.; Zhu, Y.; Yan, X.; Pan, S.; Zhang, A. Nanoflower-like Ag/AAO SERS platform with quasi-photonic crystal nanostructure for efficient detection of goat serum. Curr. Appl. Phys. 2019, 19, 1276-1285. [CrossRef]

117. Li, M.; Wu, J.; Wang, C.; Fang, J. The cascade structure of periodic micro/nanoscale Au nano-islands @ Ag-frustum arrays as effective SERS substrates. Vacuum 2020, 175, 109265. [CrossRef] 
118. Lin, B.; Kannan, P.; Qiu, B.; Lin, Z.; Guo, L. On-spot surface enhanced Raman scattering detection of Aflatoxin B1 in peanut extracts using gold nanobipyramids evenly trapped into the AAO nanoholes. Food Chem. 2020, 307, 125528. [CrossRef]

119. Hu, M.; Ou, F.S.; Wu, W.; Naumov, I.; Li, X.; Bratkovsky, A.M.; Williams, R.S.; Li, Z. Gold Nanofingers for Molecule Trapping and Detection. J. Am. Chem. Soc. 2010, 132, 12820-12822. [CrossRef]

120. Diebold, E.D.; Mack, N.H.; Doorn, S.K.; Mazur, E. Femtosecond Laser-Nanostructured Substrates for Surface-Enhanced Raman Scattering. Langmuir 2009, 25, 1790-1794. [CrossRef]

121. Aleknavičienè, I.; Pabrèža, E.; Talaikis, M.; Jankunec, M.; Račiukaitis, G. Low-cost SERS substratefeaturing laser-ablated amorphous nanostructure. Appl. Surf. Sci. 2022, 571, 151248. [CrossRef]

122. Restaino, S.M.; White, I.M. A critical review of flexible and porous SERS sensors for analytical chemistry at the point-of-sample. Anal. Chim. Acta 2019, 1060, 17-29. [CrossRef]

123. Li, L.; Yang, S.Y.; Duan, J.L.; Huang, L.; Xiao, G.N. Fabrication and SERS performance of silver nanoarrays by inkjet printing silver nanoparticles ink on the gratings of compact disc recordable. Spectrochim. Acta A-Mol. Biomol. Spectrosc. 2020, $225,117598$. [CrossRef]

124. Wu, J.; Zhang, L.; Huang, F.; Ji, X.; Dai, H.; Wu, W. Surface enhanced Raman scattering substrate for the detection of explosives: Construction strategy and dimensional effect. J. Hazard. Mater. 2020, 387, 121714. [CrossRef] [PubMed]

125. Yu, B.; Ge, M.; Li, P.; Xie, Q.; Yang, L. Development of surface-enhanced Raman spectroscopy application for determination of illicit drugs: Towards a practical sensor. Talanta 2019, 191, 1-10. [PubMed]

126. D’Apuzzo, F.; Sengupta, R.N.; Overbay, M.; Aronoff, J.S.; Rogacs, A.; Barcelo, S.J. A Generalizable Single-Chip Calibration Method for Highly Quantitative SERS via Inkjet Dispense. Anal. Chem. 2020, 92, 1372-1378. [PubMed]

127. Joshi, P.; Santhanam, V. Inkjet-Based Fabrication Process with Control over the Morphology of SERS-Active Silver Nanostructures. Ind. Eng. Chem. Res. 2018, 57, 5250-5258. [CrossRef]

128. Kumar, A.; Santhanam, V. Paper swab based SERS detection of non-permitted colourants from dals and vegetables using a portable spectrometer. Anal. Chim. Acta 2019, 1090, 106-113. [CrossRef]

129. Lan, L.L.; Hou, X.Y.; Gao, Y.M.; Fan, X.C.; Qiu, T. Inkjet-printed paper-based semiconducting substrates for surface-enhanced Raman spectroscopy. Nanotechnology 2020, 31, 055502. [CrossRef] [PubMed]

130. Li, L.; Xiao, G.N. Research Progress of Preparing Surface-Enhanced Raman Scattering Active Substrates by Printing Technologies. Spectrosc. Spectr. Anal. 2019, 39, 3326-3332.

131. Micciche, C.; Arrabito, G.; Amato, F.; Buscarino, G.; Agnello, S.; Pignataro, B. Inkjet printing Ag nanoparticles for SERS hot spots. Anal. Methods 2018, 10, 3215-3223. [CrossRef]

132. Oravec, M.; Sasinkova, V.; Tomanova, K.; Gal, L.; Parciova, S.; Huck, C.W. In-situ surface-enhanced Raman scattering and FT-Raman spectroscopy of black prints. Vib. Spectrosc. 2018, 94, 16-21. [CrossRef]

133. Weng, G.J.; Yang, Y.; Zhao, J.; Zhu, J.; Li, J.J.; Zhao, J.W. Preparation and SERS performance of Au NP/paper strips based on inkjet printing and seed mediated growth: The effect of silver ions. Solid State Commun. 2018, 272, 67-73. [CrossRef]

134. Yu, W.W.; White, I.M. Inkjet-printed paper-based SERS dipsticks and swabs for trace chemical detection. Analyst 2013, 138, 1020-1025. [CrossRef]

135. Shen, S.; Zhao, B.; Wang, H.; Li, Z.; Qu, G.; Guo, Z.; Zhou, T.; Song, W.; Wang, X.; Ruan, W. CdTe quantum dots modified polystyrene spheres with Ag nanoparticle caps: Applications both in fluorescence and in SERS. Colloids Surf. A Physicochem. Eng. Asp. 2014, 443, 467-472. [CrossRef]

136. Sammi, H.; Nair, R.V.; Sardana, N. Recent advances in nanoporous AAO based substrates for surface-enhanced raman scattering. Mater. Today Proc. 2021, 41, 843-850. [CrossRef]

137. Huang, Z.; Meng, G.; Huang, Q.; Chen, B.; Zhu, C.; Zhang, Z. Large-area Ag nanorod array substrates for SERS: AAO templateassisted fabrication, functionalization, and application in detection PCBs. J. Raman Spectrosc. 2013, 44, 240-246. [CrossRef]

138. Ruan, C.; Eres, G.; Wang, W.; Zhang, Z.; Gu, B. Controlled Fabrication of Nanopillar Arrays as Active Substrates for SurfaceEnhanced Raman Spectroscopy. Langmuir 2007, 23, 5757-5760. [CrossRef]

139. Batista, E.A.; dos Santos, D.P.; Andrade, G.F.S.; Sant'Ana, A.C.; Brolo, A.G.; Temperini, M.L.A. Using Polycarbonate Membranes as Templates for the Preparation of Au Nanostructures for Surface-Enhanced Raman Scattering. J. Nanosci. Nanotechnol. 2009, 9, 3233-3238. [CrossRef] [PubMed]

140. Penn, M.A.; Drake, D.M.; Driskell, J.D. Accelerated Surface-Enhanced Raman Spectroscopy (SERS)-Based Immunoassay on a Gold-Plated Membrane. Anal. Chem. 2013, 85, 8609-8617. [CrossRef]

141. Wigginton, K.R.; Vikesland, P.J. Gold-coated polycarbonate membrane filter for pathogen concentration and SERS-based detection. Analyst 2010, 135, 1320-1326. [CrossRef] [PubMed]

142. Piao, L.; Park, S.; Lee, H.B.; Kim, K.; Kim, J.; Chung, T.D. Single Gold Microshell Tailored to Sensitive Surface Enhanced Raman Scattering Probe. Anal. Chem. 2010, 82, 447-451. [CrossRef]

143. Wang, J.J.; Zhou, F.; Duan, G.T.; Li, Y.; Liu, G.Q.; Su, F.H.; Cai, W.P. A controlled Ag-Au bimetallic nanoshelled microsphere array and its improved surface-enhanced Raman scattering effect. RSC Adv. 2014, 4, 8758-8763. [CrossRef]

144. Zhao, Y.H.; Luo, W.Q.; Kanda, P.; Cheng, H.W.; Chen, Y.Y.; Wang, S.P.; Huan, S.Y. Silver deposited polystyrene (PS) microspheres for surface-enhanced Raman spectroscopic-encoding and rapid label-free detection of melamine in milk powder. Talanta 2013, 113, 7-13. [CrossRef] 
145. Charconnet, M.; Kuttner, C.; Plou, J.; García-Pomar, J.L.; Mihi, A.; Liz-Marzán, L.M.; Seifert, A. Mechanically Tunable LatticePlasmon Resonances by Templated Self-Assembled Superlattices for Multi-Wavelength Surface-Enhanced Raman Spectroscopy. Small Methods 2021, 5, 2100453. [CrossRef]

146. Wu, L.; Wang, W.; Zhang, W.; Su, H.; Liu, Q.; Gu, J.; Deng, T.; Zhang, D. Highly sensitive, reproducible and uniform SERS substrates with a high density of three-dimensionally distributed hotspots: Gyroid-structured Au periodic metallic materials. NPG Asia Mater. 2018, 10, e462. [CrossRef]

147. Klutse, C.K.; Mayer, A.; Wittkamper, J.; Cullum, B.M. Applications of Self-Assembled Monolayers in Surface-Enhanced Raman Scattering. J. Nanotechnol. 2012, 2012, 319038. [CrossRef]

148. Tielens, F.; Santos, E. AuS and SH Bond Formation/Breaking during the Formation of Alkanethiol SAMs on Au(111): A Theoretical Study. J. Phys. Chem. C 2010, 114, 9444-9452. [CrossRef]

149. Cohen-Atiya, M.; Mandler, D. Studying thiol adsorption on Au, Ag and $\mathrm{Hg}$ surfaces by potentiometric measurements. J. Electroanal. Chem. 2003, 550-551, 267-276. [CrossRef]

150. Xue, Y.; Li, X.; Li, H.; Zhang, W. Quantifying thiol-gold interactions towards the efficient strength control. Nat. Commun. 2014, 5, 4348. [CrossRef]

151. Inkpen, M.S.; Liu, Z.-F.; Li, H.; Campos, L.M.; Neaton, J.B.; Venkataraman, L. Non-chemisorbed gold-sulfur binding prevails in self-assembled monolayers. Nat. Chem. 2019, 11, 351-358. [CrossRef]

152. Grönbeck, H.; Curioni, A.; Andreoni, W. Thiols and Disulfides on the Au(111) Surface: The Headgroup-Gold Interaction. J. Am. Chem. Soc. 2000, 122, 3839-3842. [CrossRef]

153. Levin, C.S.; Bishnoi, S.W.; Grady, N.K.; Halas, N.J. Determining the Conformation of Thiolated Poly(ethylene glycol) on Au Nanoshells by Surface-Enhanced Raman Scattering Spectroscopic Assay. Anal. Chem. 2006, 78, 3277-3281. [CrossRef]

154. Yang, E.L.; Li, D.; Yin, P.K.; Xie, Q.Y.; Li, Y.; Lin, Q.Y.; Duan, Y.X. A novel surface-enhanced Raman scattering (SERS) strategy for ultrasensitive detection of bacteria based on three-dimensional (3D) DNA walker. Biosens. Bioelectron. 2021, 172, 112758. [CrossRef]

155. Kamińska, A.; Winkler, K.; Kowalska, A.; Witkowska, E.; Szymborski, T.; Janeczek, A.; Waluk, J. SERS-based Immunoassay in a Microfluidic System for the Multiplexed Recognition of Interleukins from Blood Plasma: Towards Picogram Detection. Sci. Rep. 2017, 7, 10656. [CrossRef]

156. Oss, C.J.V. Antibody-Antigen Intermolecular Forces. In Encyclopedia of Immunology, 2nd ed.; Elsevier: Amsterdam, The Netherlands, 1998; pp. 163-167.

157. Kim, H.; Kang, H.; Kim, H.-N.; Kim, H.; Moon, J.; Guk, K.; Park, H.; Yong, D.; Bae, P.K.; Park, H.G.; et al. Development of 6E3 antibody-mediated SERS immunoassay for drug-resistant influenza virus. Biosens. Bioelectron. 2021, 187, 113324. [CrossRef]

158. He, D.Y.; Wu, Z.Z.; Cui, B.; Xu, E.B. Aptamer and gold nanorod-based fumonisin B1 assay using both fluorometry and SERS. Microchim. Acta 2020, 187, 215. [CrossRef]

159. He, X.; Zhou, X.; Liu, Y.; Wang, X.L. Ultrasensitive, recyclable and portable microfluidic surface-enhanced raman scattering (SERS) biosensor for uranyl ions detection. Sens. Actuators B Chem. 2020, 311, 127676. [CrossRef]

160. Huang, D.D.; Chen, J.M.; Ding, L.; Guo, L.H.; Kannan, P.; Luo, F.; Qiu, B.; Lin, Z.Y. Core-satellite assemblies and exonuclease assisted double amplification strategy for ultrasensitive SERS detection of biotoxin. Anal. Chim. Acta 2020, 1110, 56-63. [CrossRef] [PubMed]

161. Wang, J.R.; Xia, C.; Yang, L.; Li, Y.F.; Li, C.M.; Huang, C.Z. DNA Nanofirecrackers Assembled through Hybridization Chain Reaction for Ultrasensitive SERS Immunoassay of Prostate Specific Antigen. Anal. Chem. 2020, 92, 4046-4052. [CrossRef] [PubMed]

162. Wang, Q.; Hu, Y.J.; Jiang, N.J.; Wang, J.J.; Yu, M.; Zhuang, X.M. Preparation of Aptamer Responsive DNA Functionalized Hydrogels for the Sensitive Detection of alpha-Fetoprotein Using SERS Method. Bioconjugate Chem. 2020, 31, 813-820. [CrossRef] [PubMed]

163. Zhou, S.S.; Lu, C.; Li, Y.Z.; Xue, L.; Zhao, C.Y.; Tian, G.F.; Bao, Y.M.; Tang, L.H.; Lin, J.H.; Zheng, J.K. Gold Nanobones Enhanced Ultrasensitive Surface-Enhanced Raman Scattering Aptasensor for Detecting Escherichia coil O157:H7. ACS Sens. 2020, 5, 588-596. [CrossRef] [PubMed]

164. Šimáková, P.; Gautier, J.; Procházka, M.; Hervé-Aubert, K.; Chourpa, I. Polyethylene-glycol-Stabilized Ag Nanoparticles for Surface-Enhanced Raman Scattering Spectroscopy: Ag Surface Accessibility Studied Using Metalation of Free-Base Porphyrins. J. Phys. Chem. C 2014, 118, 7690-7697. [CrossRef]

165. Lin, D.; Hsieh, C.-L.; Hsu, K.-C.; Liao, P.-H.; Qiu, S.; Gong, T.; Yong, K.-T.; Feng, S.; Kong, K.V. Geometrically encoded SERS nanobarcodes for the logical detection of nasopharyngeal carcinoma-related progression biomarkers. Nat. Commun. 2021, 12, 3430. [CrossRef]

166. Jeyaratnam, J. Acute pesticide poisoning: A major global health problem. World Health Stat. Q. 1990, 43, 139-144.

167. Aktar, M.W.; Sengupta, D.; Chowdhury, A. Impact of pesticides use in agriculture: Their benefits and hazards. Interdiscip. Toxicol. 2009, 2, 1-12. [CrossRef]

168. Food Agriculture Organization. International Code of Conduct on the Distribution and Use of Pesticides; United Nations: Rome, Italy, 2005.

169. Han, L.J.; Sapozhnikova, Y. Semi-automated high-throughput method for residual analysis of 302 pesticides and environmental contaminants in catfish by fast low-pressure GC-MS/MS and UHPLC-MS/MS. Food Chem. 2020, 319, 126592. [CrossRef] 
170. Velkoska-Markovska, L.; Petanovska-Ilievska, B. Rapid Resolution Liquid Chromatography Method for Determination of Malathion in Pesticide Formulation. Acta Chromatogr. 2020, 32, 256-259. [CrossRef]

171. Geto, A.; Noori, J.S.; Mortensen, J.; Svendsen, W.E.; Dimaki, M. Electrochemical determination of bentazone using simple screen-printed carbon electrodes. Environ. Int. 2019, 129, 400-407. [CrossRef]

172. Santana, P.C.A.; Lima, J.B.S.; Santana, T.B.S.; Santos, L.F.S.; Matos, C.R.S.; da Costa, L.P.; Gimenez, I.F.; Sussuchi, E.M. Semiconductor Nanocrystals-Reduced Graphene Composites for the Electrochemical Detection of Carbendazim. J. Braz. Chem. Soc. 2019, 30, 1302-1308. [CrossRef]

173. Alak, A.M.; Vo-Dinh, T. Surface-enhanced Raman spectrometry of organo phosphorus chemical agents. Anal. Chem. 1987, 59, 2149-2153. [CrossRef]

174. European Food Safety Authority. The 2010 European Union Report on Pesticide Residues in Food. EFSA J. 2013, 11, 3130.

175. Song, D.; Yang, R.; Long, F.; Zhu, A. Applications of magnetic nanoparticles in surface-enhanced Raman scattering (SERS) detection of environmental pollutants. J. Environ. Sci. 2019, 80, 14-34. [CrossRef] [PubMed]

176. Fan, Y.X.; Lai, K.Q.; Rasco, B.A.; Huang, Y.Q. Analyses of phosmet residues in apples with surface-enhanced Raman spectroscopy. Food Control 2014, 37, 153-157. [CrossRef]

177. Liu, B.; Zhou, P.; Liu, X.M.; Sun, X.; Li, H.; Lin, M.S. Detection of Pesticides in Fruits by Surface-Enhanced Raman Spectroscopy Coupled with Gold Nanostructures. Food Bioprocess Technol. 2013, 6, 710-718. [CrossRef]

178. Yaseen, T.; Pu, H.B.; Sun, D.W. Rapid detection of multiple organophosphorus pesticides (triazophos and parathion-methyl) residues in peach by SERS based on core-shell bimetallic Au@Ag NPs. Food Addit. Contam. A-Chem. Anal. Control Expo. Risk Assess. 2019, 36, 762-778. [CrossRef]

179. Benitta, T.A.; Kapoor, S.; Christy, R.S.; Raj, C.I.S.; Kumaran, J.T.T. Surface Enhanced Raman Spectra and Theoretical Study of an Organophosphate Malathion. Orient. J. Chem. 2017, 33, 760-767. [CrossRef]

180. Nie, Y.H.; Teng, Y.J.; Li, P.; Liu, W.H.; Shi, Q.W.; Zhang, Y.C. Label-free aptamer-based sensor for specific detection of malathion residues by surface-enhanced Raman scattering. Spectrochim. Acta A-Mol. Biomol. Spectrosc. 2018, 191, 271-276. [CrossRef]

181. Banks, K.E.; Hunter, D.H.; Wachal, D.J. Chlorpyrifos in surface waters before and after a federally mandated ban. Environ. Int. 2005, 31, 351-356. [CrossRef]

182. Feng, S.L.; Hu, Y.X.; Ma, L.Y.; Lu, X.N. Development of molecularly imprinted polymers-surface-enhanced Raman spectroscopy/colorimetric dual sensor for determination of chlorpyrifos in apple juice. Sens. Actuators B Chem. 2017, 241, 750-757. [CrossRef]

183. Ma, P.; Wang, L.Y.; Xu, L.; Li, J.Y.; Zhang, X.D.; Chen, H. Rapid quantitative determination of chlorpyrifos pesticide residues in tomatoes by surface-enhanced Raman spectroscopy. Eur. Food Res. Technol. 2020, 246, 239-251. [CrossRef]

184. Hussain, A.; Sun, D.W.; Pu, H.B. Bimetallic core shelled nanoparticles (Au@AgNPs) for rapid detection of thiram and dicyandiamide contaminants in liquid milk using SERS. Food Chem. 2020, 317, 126429. [CrossRef]

185. Hu, X.N.; Bian, X.Z.; Yu, S.Z.; Dan, K. Magnetic Fe3O4@SiO2@Ag@COOH NPs/Au Film with Hybrid Localized Surface Plasmon/Surface Plasmon Polariton Modes for Surface-Enhanced Raman Scattering Detection of Thiabendazole. J. Nanosci. Nanotechnol. 2020, 20, 2079-2086. [CrossRef]

186. Wang, K.Q.; Sun, D.W.; Pu, H.B.; Wei, Q.Y. Two-dimensional Au@Ag nanodot array for sensing dual-fungicides in fruit juices with surface-enhanced Raman spectroscopy technique. Food Chem. 2020, 310, 125923. [CrossRef] [PubMed]

187. Costa, J.C.S.; Ando, R.A.; Sant'Ana, A.C.; Rossi, L.M.; Santos, P.S.; Temperini, M.L.A.; Corio, P. High performance gold nanorods and silver nanocubes in surface-enhanced Raman spectroscopy of pesticides. Phys. Chem. Chem. Phys. 2009, 11, 7491-7498. [CrossRef] [PubMed]

188. Dowgiallo, A.M. Trace level pesticide detection utilizing gold nanoparticles and surface enhanced Raman spectroscopy (SERS). In Synthesis and Photonics of Nanoscale Materials XVI; Kabashin, A.V., Dubowski, J.J., Geohegan, D.B., Eds.; SPIE: Washington, DC, USA, 2019; Volume 10907.

189. Wang, Q.; Zhao, Y.; Bu, T.; Wang, X.; Xu, Z.; Zhangsun, H.; Wang, L. Semi-sacrificial template growth-assisted self-supporting MOF chip: A versatile and high-performance SERS sensor for food contaminants monitoring. Sens. Actuators B Chem. 2022, 352, 131025. [CrossRef]

190. Canamares, M.V.; Feis, A. Surface-enhanced Raman spectra of the neonicotinoid pesticide thiacloprid. J. Raman Spectrosc. 2013, 44, 1126-1135. [CrossRef]

191. Wu, J.; Xi, J.; Chen, H.; Li, S.; Zhang, L.; Li, P.; Wu, W. Flexible 2D nanocellulose-based SERS substrate for pesticide residue detection. Carbohydr. Polym. 2022, 277, 118890. [CrossRef]

192. Lu, Y.; Tan, Y.; Xiao, Y.; Li, Z.; Sheng, E.; Dai, Z. A silver@gold nanoparticle tetrahedron biosensor for multiple pesticides detection based on surface-enhanced Raman scattering. Talanta 2021, 234, 122585. [CrossRef]

193. Zaim, M.; Jambulingam, P. Global Insecticide Use for Vector-Borne Disease Control; World Health Organization: Geneva, Switzerland, 2007.

194. Kozawa, K.; Aoyama, Y.; Mashimo, S.; Kimura, H. Toxicity and actual regulation of organophosphate pesticides. Toxin Rev. 2009, 28, 245-254. [CrossRef]

195. Rosenstock, L.; Keifer, M.; Daniell, W.E.; McConnell, R.; Claypoole, K.; The Pesticide Health Effects Study Group. Chronic central nervous system effects of acute organophosphate pesticide intoxication. Lancet 1991, 338, 223-227. [CrossRef] 
196. Eskenazi, B.; Bradman, A.; Castorina, R. Exposures of children to organophosphate pesticides and their potential adverse health effects. Environ. Health Perspect. 1999, 107 (Suppl. 3), 409-419. [CrossRef] [PubMed]

197. Stephens, R.; Spurgeon, A.; Calvert, I.A.; Beach, J.; Levy, L.S.; Harrington, J.; Berry, H. Neuropsychological effects of long-term exposure to organophosphates in sheep dip. Lancet 1995, 345, 1135-1139. [CrossRef]

198. Fries, E.; Püttmann, W. Occurrence of organophosphate esters in surface water and ground water in Germany. J. Environ. Monit. 2001, 3, 621-626. [CrossRef]

199. Karalliedde, L.; Eddleston, M.; Murray, V. The Global Picture of Organophosphate Insecticide Poisoning; World Scientific: Singapore, 2001; pp. 431-471.

200. Pogačnik, L.; Franko, M. Determination of organophosphate and carbamate pesticides in spiked samples of tap water and fruit juices by a biosensor with photothermal detection. Biosens. Bioelectron. 1999, 14, 569-578. [CrossRef]

201. Syafrudin, M.; Kristanti, R.A.; Yuniarto, A.; Hadibarata, T.; Rhee, J.; Al-onazi, W.A.; Algarni, T.S.; Almarri, A.H.; Al-Mohaimeed, A.M. Pesticides in Drinking Water-A Review. Int. J. Environ. Res. Public Health 2021, 18, 468. [CrossRef] [PubMed]

202. Liu, B.; Han, G.; Zhang, Z.; Liu, R.; Jiang, C.; Wang, S.; Han, M.-Y. Shell Thickness-Dependent Raman Enhancement for Rapid Identification and Detection of Pesticide Residues at Fruit Peels. Anal. Chem. 2012, 84, 255-261. [CrossRef]

203. Li, J.F.; Huang, Y.F.; Ding, Y.; Yang, Z.L.; Li, S.B.; Zhou, X.S.; Fan, F.R.; Zhang, W.; Zhou, Z.Y.; Wu, D.Y.; et al. Shell-isolated nanoparticle-enhanced Raman spectroscopy. Nature 2010, 464, 392-395. [CrossRef]

204. Chen, X.; Wang, D.H.; Li, J.; Xu, T.T.; Lai, K.Q.; Ding, Q.; Lin, H.T.; Sun, L.; Lin, M.S. A spectroscopic approach to detect and quantify phosmet residues in Oolong tea by surface-enhanced Raman scattering and silver nanoparticle substrate. Food Chem. 2020, 312, 126016. [CrossRef]

205. Jiang, L.; Gu, K.J.; Liu, R.Y.; Jin, S.Z.; Wang, H.Q.; Pan, C.P. Rapid detection of pesticide residues in fruits by surface-enhanced Raman scattering based on modified QuEChERS pretreatment method with portable Raman instrument. SN Appl. Sci. 2019, 1, 627. [CrossRef]

206. Weng, S.Z.; Zhu, W.X.; Dong, R.L.; Zheng, L.; Wang, F. Rapid Detection of Pesticide Residues in Paddy Water Using SurfaceEnhanced Raman Spectroscopy. Sensors 2019, 19, 506. [CrossRef]

207. Kang, Y.; Wu, T.; Chen, W.C.; Li, L.; Du, Y.P. A novel metastable state nanoparticle-enhanced Raman spectroscopy coupled with thin layer chromatography for determination of multiple pesticides. Food Chem. 2019, 270, 494-501. [CrossRef]

208. Kang, Y.; Li, L.; Chen, W.C.; Zhang, F.Y.; Du, Y.P.; Wu, T. Rapid In Situ SERS Analysis of Pesticide Residues on Plant Surfaces Based on Micelle Extraction of Targets and Stabilization of Ag Nanoparticle Aggregates. Food Anal. Methods 2018, 11, 3161-3169. [CrossRef]

209. Huang, D.D.; Zhao, J.C.; Wang, M.L.; Zhu, S.H. Snowflake-like gold nanoparticles as SERS substrates for the sensitive detection of organophosphorus pesticide residues. Food Control 2020, 108, 106835. [CrossRef]

210. Tang, F.; Zhang, M.Z.; Li, Z.B.; Du, Z.F.; Chen, B.S.; He, X.; Zhao, S.Y. Hexagonally arranged arrays of urchin-like Ag-nanoparticle decorated ZnO-nanorods grafted on PAN-nanopillars as surface-enhanced Raman scattering substrates. CrystEngComm 2018, 20, 3550-3558. [CrossRef]

211. Yazdi, S.H.; White, I.M. A nanoporous optofluidic microsystem for highly sensitive and repeatable surface enhanced Raman spectroscopy detection. Biomicrofluidics 2012, 6, 014105. [CrossRef]

212. Fathi, F.; Lagugne-Labarthet, F.; Pedersen, D.B.; Kraatz, H.B. Studies of the interaction of two organophosphonates with nanostructured silver surfaces. Analyst 2012, 137, 4448-4453. [CrossRef]

213. Dowgiallo, A.M.; Guenther, D.A. Determination of the Limit of Detection of Multiple Pesticides Utilizing Gold Nanoparticles and Surface-Enhanced Raman Spectroscopy. J. Agric. Food Chem. 2019, 67, 12642-12651. [CrossRef]

214. Tang, J.S.; Chen, W.W.; Ju, H.X. Rapid detection of pesticide residues using a silver nanoparticles coated glass bead as nonplanar substrate for SERS sensing. Sens. Actuators B Chem. 2019, 287, 576-583. [CrossRef]

215. Elbert, A.; Haas, M.; Springer, B.; Thielert, W.; Nauen, R. Applied aspects of neonicotinoid uses in crop protection. Pest Manag. Sci. 2008, 64, 1099-1105. [CrossRef] [PubMed]

216. Jeschke, P.; Nauen, R. Neonicotinoids-From zero to hero in insecticide chemistry. Pest Manag. Sci. 2008, 64, 1084-1098. [CrossRef]

217. Lee, J.K.; Ahn, K.C.; Park, O.S.; Kang, S.Y.; Hammock, B.D. Development of an ELISA for the Detection of the Residues of the Insecticide Imidacloprid in Agricultural and Environmental Samples. J. Agric. Food Chem. 2001, 49, 2159-2167. [CrossRef] [PubMed]

218. Watanabe, E.; Baba, K.; Eun, H.; Miyake, S. Application of a commercial immunoassay to the direct determination of insecticide imidacloprid in fruit juices. Food Chem. 2007, 102, 745-750. [CrossRef]

219. Obana, H.; Okihashi, M.; Akutsu, K.; Kitagawa, Y.; Hori, S. Determination of Acetamiprid, Imidacloprid, and Nitenpyram Residues in Vegetables and Fruits by High-Performance Liquid Chromatography with Diode-Array Detection. J. Agric. Food Chem. 2002, 50, 4464-4467. [CrossRef]

220. Liu, S.; Zheng, Z.; Wei, F.; Ren, Y.; Gui, W.; Wu, H.; Zhu, G. Simultaneous Determination of Seven Neonicotinoid Pesticide Residues in Food by Ultraperformance Liquid Chromatography Tandem Mass Spectrometry. J. Agric. Food Chem. 2010, 58, 3271-3278. [CrossRef]

221. Ding, X.; Zhang, W.; Cheng, D.; He, J.; Yang, K.-L. Oligopeptides functionalized surface plasmon resonance biosensors for detecting thiacloprid and imidacloprid. Biosens. Bioelectron. 2012, 35, 271-276. [CrossRef] [PubMed] 
222. Vílchez, J.L.; Valencia, M.C.; Navalón, A.; Molinero-Morales, B.; Capitán-Vallvey, L.F. Flow injection analysis of the insecticide imidacloprid in water samples with photochemically induced fluorescence detection. Anal. Chim. Acta 2001, 439, $299-305$. [CrossRef]

223. Nauen, R.; Bretschneider, T. New modes of action of insecticides. Pestic. Outlook 2002, 13, 241-245. [CrossRef]

224. Tomizawa, M.; Casida, J.E. Neonicotinoid insecticide toxicology: Mechanisms of selective action. Annu. Rev. Pharmacol. Toxicol. 2005, 45, 247-268. [CrossRef]

225. Whitehorn, P.R.; O'Connor, S.; Wackers, F.L.; Goulson, D. Neonicotinoid pesticide reduces bumble bee colony growth and queen production. Science 2012, 336, 351-352. [CrossRef]

226. European Commission. Commission Implementing Regulation (EU) No 485/2013 of 24 May 2013 amending Implementing Regulation (EU) No 540/2011, as regards the conditions of approval of the active substances clothianidin, thiamethoxam and imidacloprid, and prohibiting the use and sale of seeds treated with plant protection products containing those active substances. Off. J. Eur. Union 2013, 139, 12-14.

227. Ferrer, I.; Thurman, E.M.; Fernández-Alba, A.R. Quantitation and Accurate Mass Analysis of Pesticides in Vegetables by LC/TOF-MS. Anal. Chem. 2005, 77, 2818-2825. [CrossRef] [PubMed]

228. European Food Safety Authority. The 2014 European Union Report on Pesticide Residues in Food. EFSA J. 2016,14 , e04611. [CrossRef]

229. Cao, X.L.; Hong, S.H.; Jiang, Z.J.; She, Y.X.; Wang, S.S.; Zhang, C.; Li, H.; Jin, F.; Jin, M.J.; Wang, J. SERS-active metal-organic frameworks with embedded gold nanoparticles. Analyst 2017, 142, 2640-2647. [CrossRef] [PubMed]

230. Yang, T.; Zhao, B.; Hou, R.; Zhang, Z.; Kinchla, A.J.; Clark, J.M.; He, L. Evaluation of the Penetration of Multiple Classes of Pesticides in Fresh Produce Using Surface-Enhanced Raman Scattering Mapping. J. Food Sci. 2016, 81, T2891-T2901. [CrossRef]

231. Wijaya, W.; Pang, S.; Labuza, T.P.; He, L. Rapid Detection of Acetamiprid in Foods using Surface-Enhanced Raman Spectroscopy (SERS). J. Food Sci. 2014, 79, T743-T747. [CrossRef] [PubMed]

232. Sun, Y.; Li, Z.H.; Huang, X.W.; Zhang, D.; Zou, X.B.; Shi, J.Y.; Zhai, X.D.; Jiang, C.P.; Wei, X.O.; Liu, T.T. A nitrile-mediated aptasensor for optical anti-interference detection of acetamiprid in apple juice by surface-enhanced Raman scattering. Biosens. Bioelectron. 2019, 145, 111672. [CrossRef]

233. Feng, X.Z.; Li, C.N.; Liang, A.H.; Luo, Y.H.; Jiang, Z.L. Doped N/Ag Carbon Dot Catalytic Amplification SERS Strategy for Acetamiprid Coupled Aptamer with 3,3'-Dimethylbiphenyl-4,4'-diamine Oxidizing Reaction. Nanomaterials 2019, 9, 480. [CrossRef]

234. Li, H.H.; Hu, W.W.; Hassan, M.M.; Zhang, Z.Z.; Chen, Q.S. A facile and sensitive SERS-based biosensor for colormetric detection of acetamiprid in green tea based on unmodified gold nanoparticles. J. Food Meas. Charact. 2019, 13, 259-268. [CrossRef]

235. Zhao, P.N.; Liu, H.Y.; Zhang, L.N.; Zhu, P.H.; Ge, S.G.; Yu, J.H. Paper-Based SERS Sensing Platform Based on 3D Silver Dendrites and Molecularly Imprinted Identifier Sandwich Hybrid for Neonicotinoid Quantification. ACS Appl. Mater. Interfaces 2020, 12, 8845-8854. [CrossRef] [PubMed]

236. Chen, Q.S.; Hassan, M.M.; Xu, J.; Zareef, M.; Li, H.H.; Xu, Y.; Wang, P.Y.; Agyekum, A.A.; Kutsanedzie, F.Y.H.; Viswadevarayalu, A. Fast sensing of imidacloprid residue in tea using surface-enhanced Raman scattering by comparative multivariate calibration. Spectrochim. Acta A-Mol. Biomol. Spectrosc. 2019, 211, 86-93. [CrossRef]

237. Qiu, H.W.; Guo, J.; Wang, M.Q.; Ji, S.D.; Cao, M.H.; Padhiar, M.A.; Bhatti, A.S. Reduced graphene oxide supporting Ag mesoflowers and phenyl-modified graphitic carbon nitride as self-cleaning flexible SERS membrane for molecular trace-detection. Colloids Surf. A-Physicochem. Eng. Asp. 2019, 560, 9-19. [CrossRef]

238. Creedon, N.; Lovera, P.; Moreno, J.G.; Nolan, M.; O'Riordan, A. Highly Sensitive SERS Detection of Neonicotinoid Pesticides. Complete Raman Spectral Assignment of Clothianidin and Imidacloprid. J. Phys. Chem. A 2020, 124, 7238-7247. [CrossRef] [PubMed]

239. Hou, R.Y.; Pang, S.; He, L.L. In situ SERS detection of multi-class insecticides on plant surfaces. Anal. Methods 2015, 7, 6325-6330. [CrossRef]

240. Xu, Y.; Kutsanedzie, F.Y.H.; Hassan, M.; Zhu, J.J.; Ahmad, W.; Li, H.H.; Chen, Q.S. Mesoporous silica supported orderly-spaced gold nanoparticles SERS-based sensor for pesticides detection in food. Food Chem. 2020, 315, 126300. [CrossRef]

241. Atanasov, P.A.; Nedyalkov, N.N.; Nikov, R.G.; Fukata, N.; Jevasuwan, W.; Subramani, T.; Hirsch, D.; Rauschenbach, B. SERS analyses of thiamethoxam assisted by Ag films and nanostructures produced by laser techniques. J. Raman Spectrosc. 2018, 49, 397-403. [CrossRef]

242. Atanasov, P.A.; Nedyalkov, N.N.; Fukata, N.; Jevasuwan, W.; Subramani, T. Surface-Enhanced Raman Spectroscopy (SERS) of Neonicotinoid Insecticide Thiacloprid Assisted by Silver and Gold Nanostructures. Appl. Spectrosc. 2020, 74, 357-364. [CrossRef]

243. Srivastava, S.; Sinha, R.; Roy, D. Toxicological effects of malachite green. Aquat. Toxicol. 2004, 66, 319-329. [CrossRef]

244. Stammati, A.; Nebbia, C.; de Angelis, I.; Albo, A.G.; Carletti, M.; Rebecchi, C.; Zampaglioni, F.; Dacasto, M. Effects of malachite green (MG) and its major metabolite, leucomalachite green (LMG), in two human cell lines. Toxicol. Vitr. 2005, 19, 853-858. [CrossRef] [PubMed]

245. Kneipp, K.; Wang, Y.; Kneipp, H.; Perelman, L.T.; Itzkan, I.; Dasari, R.R.; Feld, M.S. Single Molecule Detection Using SurfaceEnhanced Raman Scattering (SERS). Phys. Rev. Lett. 1997, 78, 1667-1670. [CrossRef]

246. Michaels, A.M.; Nirmal, M.; Brus, L. Surface enhanced Raman spectroscopy of individual rhodamine 6G molecules on large Ag nanocrystals. J. Am. Chem. Soc. 1999, 121, 9932-9939. [CrossRef] 
247. Gossner, C.; Schlundt, J.; Embarek, P.; Hird, S.; Lo-Fo-Wong, D.; Beltran, J.; Teoh, K.N.; Tritscher, A. The Melamine Incident: Implications for International Food and Feed Safety. Environ. Health Perspect. 2009, 117, 1803-1808. [CrossRef] [PubMed]

248. Zhang, X.F.; Zou, M.Q.; Qi, X.H.; Liu, F.; Zhu, X.H.; Zhao, B.H. Detection of melamine in liquid milk using surface-enhanced Raman scattering spectroscopy. J. Raman Spectrosc. 2010, 41, 1655-1660. [CrossRef]

249. Lee, S.Y.; Ganbold, E.-O.; Choo, J.; Joo, S.-W. Detection of Melamine in Powdered Milk Using Surface-Enhanced Raman Scattering with No Pretreatment. Anal. Lett. 2010, 43, 2135-2141. [CrossRef]

250. Mecker, L.C.; Tyner, K.M.; Kauffman, J.F.; Arzhantsev, S.; Mans, D.J.; Gryniewicz-Ruzicka, C.M. Selective melamine detection in multiple sample matrices with a portable Raman instrument using surface enhanced Raman spectroscopy-active gold nanoparticles. Anal. Chim. Acta 2012, 733, 48-55. [CrossRef] [PubMed]

251. Giovannozzi, A.M.; Rolle, F.; Sega, M.; Abete, M.C.; Marchis, D.; Rossi, A.M. Rapid and sensitive detection of melamine in milk with gold nanoparticles by Surface Enhanced Raman Scattering. Food Chem. 2014, 159, 250-256. [CrossRef]

252. Lou, T.T.; Wang, Y.Q.; Li, J.H.; Peng, H.L.; Xiong, H.; Chen, L.X. Rapid detection of melamine with 4-mercaptopyridine-modified gold nanoparticles by surface-enhanced Raman scattering. Anal. Bioanal. Chem. 2011, 401, 333-338. [CrossRef]

253. Yazgan, N.N.; Boyaci, I.H.; Topcu, A.; Tamer, U. Detection of melamine in milk by surface-enhanced Raman spectroscopy coupled with magnetic and Raman-labeled nanoparticles. Anal. Bioanal. Chem. 2012, 403, 2009-2017. [CrossRef] [PubMed]

254. Tang, J.Q.; Tian, C.; Zeng, C.Y.; Man, S.Q. Alkaline Silver Colloid for Surface Enhanced Raman Scattering and Application to Detection of Melamine Doped Milk. Spectrosc. Spectr. Anal. 2013, 33, 709-713.

255. Betz, J.F.; Cheng, Y.; Rubloff, G.W. Direct SERS detection of contaminants in a complex mixture: Rapid, single step screening for melamine in liquid infant formula. Analyst 2012, 137, 826-828. [CrossRef] [PubMed]

256. Chen, L.M.; Liu, Y.N. Surface-Enhanced Raman Detection of Melamine on Silver-Nanoparticle-Decorated Silver/Carbon Nanospheres: Effect of Metal Ions. ACS Appl. Mater. Interfaces 2011, 3, 3091-3096. [CrossRef] [PubMed]

257. Li, J.M.; Ma, W.F.; Wei, C.; You, L.J.; Guo, J.; Hu, J.; Wang, C.C. Detecting Trace Melamine in Solution by SERS Using Ag Nanoparticle Coated Poly(styrene-co-acrylic acid) Nanospheres as Novel Active Substrates. Langmuir 2011, 27, 14539-14544. [CrossRef]

258. Ma, P.Y.; Liang, F.H.; Sun, Y.; Jin, Y.; Chen, Y.; Wang, X.H.; Zhang, H.Q.; Gao, D.J.; Song, D.Q. Rapid determination of melamine in milk and milk powder by surface-enhanced Raman spectroscopy and using cyclodextrin-decorated silver nanoparticles. Microchim. Acta 2013, 180, 1173-1180. [CrossRef]

259. Kumar, S.V.; Huang, N.M.; Lim, H.N.; Zainy, M.; Harrison, I.; Chia, C.H. Preparation of highly water dispersible functional graphene/silver nanocomposite for the detection of melamine. Sens. Actuators B Chem. 2013, 181, 885-893. [CrossRef]

260. Peng, B.; Li, G.Y.; Li, D.H.; Dodson, S.; Zhang, Q.; Zhang, J.; Lee, Y.H.; Demir, H.V.; Ling, X.Y.; Xiong, Q.H. Vertically Aligned Gold Nanorod Monolayer on Arbitrary Substrates: Self-Assembly and Femtomolar Detection of Food Contaminants. ACS Nano 2013, 7, 5993-6000. [CrossRef]

261. Hu, H.; Wang, Z.; Pan, L.; Zhao, S.; Zhu, S. Ag-Coated Fe3O4@SiO2 Three-Ply Composite Microspheres: Synthesis, Characterization, and Application in Detecting Melamine with Their Surface-Enhanced Raman Scattering. J. Phys. Chem. C 2010, 114, 7738-7742. [CrossRef]

262. Guo, Z.; Cheng, Z.; Li, R.; Chen, L.; Lv, H.; Zhao, B.; Choo, J. One-step detection of melamine in milk by hollow gold chip based on surface-enhanced Raman scattering. Talanta 2014, 122, 80-84. [CrossRef]

263. Chen, L.M.; Luo, L.B.; Chen, Z.H.; Zhang, M.L.; Zapien, J.A.; Lee, C.S.; Lee, S.T. ZnO/Au Composite Nanoarrays As Substrates for Surface-Enhanced Raman Scattering Detection. J. Phys. Chem. C 2010, 114, 93-100. [CrossRef]

264. Kim, A.; Barcelo, S.J.; Williams, R.S.; Li, Z.Y. Melamine Sensing in Milk Products by Using Surface Enhanced Raman Scattering. Anal. Chem. 2012, 84, 9303-9309. [CrossRef] [PubMed]

265. Subaihi, A.; Xu, Y.; Muhamadali, H.; Mutter, S.T.; Blanch, E.W.; Ellis, D.I.; Goodacre, R. Towards improved quantitative analysis using surface-enhanced Raman scattering incorporating internal isotope labelling. Anal. Methods 2017, 9, 6636-6644. [CrossRef] 